\title{
High-Affinity Zinc Inhibition of NMDA NR1-NR2A Receptors
}

\author{
Pierre Paoletti, Philippe Ascher, and Jacques Neyton \\ Laboratoire de Neurobiologie, Centre National de la Recherche Scientifique Unité de Recherche Associée 1857, Ecole \\ Normale Supérieure, 75005 Paris, France
}

\begin{abstract}
Micromolar concentrations of extracellular $\mathrm{Zn}^{2+}$ are known to antagonize native NMDA receptors via a dual mechanism involving both a voltage-independent and a voltage-dependent inhibition. We have tried to evaluate the relative importance of these two effects and their subunit specificity on recombinant NMDA receptors expressed in HEK 293 cells and Xenopus oocytes. The comparison of NR1a-NR2A and NR1a-NR2B receptors shows that the voltage-dependent inhibition is similar in both types of receptors but that the voltage-independent inhibition occurs at much lower $\mathrm{Zn}^{2+}$ concentrations in NR1a$\mathrm{NR} 2 \mathrm{~A}$ receptors $\left(\mathrm{IC}_{50}\right.$ in the nanomolar range) than in NR1aNR2B receptors ( $\mathrm{IC}_{50}$ in the micromolar range). The high affinity of the effect observed with NR1a-NR2A receptors was found to be attributable mostly to the slow dissociation of $\mathrm{Zn}^{2+}$ from its binding site. By analyzing the effects of $\mathrm{Zn}^{2+}$ on varied com-
\end{abstract}

binations of NR1 (NR1a or NR1b) and NR2 (NR2A, NR2B, NR2C), we show that both the NR1 and the NR2 subunits contribute to the voltage-independent $\mathrm{Zn}^{2+}$ inhibition. We have observed further that under control conditions, i.e., in zero nominal $\mathrm{Zn}^{2+}$ solutions, the addition of low concentrations of heavy metal chelators markedly potentiates the responses of NR1a-NR2A receptors, but not of NR1a-NR2B receptors. This result suggests that traces of a heavy metal (probably $\mathrm{Zn}^{2+}$ ) contaminate standard solutions and tonically inhibit NR1aNR2A receptors. Chelation of a contaminant metal also could account for the rapid NR2A subunit-specific potentiations produced by reducing compounds like DTT or glutathione.

Key words: NMDA; zinc; DTT; heavy metals; recombinant receptors; ionic channels
$\mathrm{Zn}^{2+}$ ions are known to be abundant in some nerve terminals and can be released in the synaptic cleft at concentrations of nearly $1 \mu \mathrm{M}$ (for review, see Smart et al., 1994). In this context, the observation that $\mathrm{Zn}^{2+}$ at micromolar concentrations inhibits NMDA responses (Peters et al., 1987; Westbrook and Mayer, 1987) immediately was given a major physiological significance. This significance was reinforced by the observation of $\mathrm{Zn}^{2+}$ inhibitory effects on the NMDA components of synaptic currents (Forsythe et al., 1988; Mayer and Vyklicky, 1989) and by data indicating that $\mathrm{Zn}^{2+}$ could play an important role in excitoxicity (Koh and Choi, 1988; Koh et al., 1996).

The analysis of the mechanisms of the $\mathrm{Zn}^{2+}$ inhibition (Mayer et al., 1988, 1989; Christine and Choi, 1990; Legendre and Westbrook, 1990) revealed that $\mathrm{Zn}^{2+}$ produces both a voltageindependent inhibition and a voltage-dependent block, the latter resembling that produced by $\mathrm{Mg}^{2+}$. Inhibitory effects of $\mathrm{Zn}^{2+}$ on recombinant NMDA receptors were observed first on receptors expressed from whole brain RNA (Rassendren et al., 1990) and then, after the cloning of the main NMDA receptor subunits, on heteromeric receptors associating NR1 and NR2 subunits (Kutsuwada et al., 1992; Meguro et al., 1992) and on most homomeric NR1 receptors (Hollmann et al., 1993; Zheng et al., 1994). Mori

Received March 31, 1997; revised May 8, 1997; accepted May 13, 1997.

This work was supported by the Ministère de l'Enseignement Supérieure et de la Recherche, the Université Pierre et Marie Curie, and the Fondation pour la Recherche Médicale. We thank Boris Barbour for comments on this manuscript, Mariano Casado, who helped in some crucial HEK experiments, and Dani Lévy for culturing the neurons.

Correspondence should be addressed to Dr. Jacques Neyton, Laboratoire de Neurobiologie, Ecole Normale Supérieure, 46 Rue d’Ulm, 75005 Paris, France.

Dr. Paoletti's present address: Center for Neurobiology and Behavior, Howard Hughes Medical Institute, Columbia University, 722 West 168th Street, New York, NY 10032.

Copyright (C) 1997 Society for Neuroscience $0270-6474 / 97 / 175611-15 \$ 05.00 / 0$ et al. (1992) and Sakurada et al. (1993) then analyzed the effects of mutations of a ring of asparagines found at the $\mathrm{Q} / \mathrm{R} / \mathrm{N}$ site, $\mathrm{a}$ critical position of the M2 segment involved in the control of the $\mathrm{Mg}^{2+}$ block of NMDA channels (see McBain and Mayer, 1994). They observed that a major reduction or even a complete suppression of the $\mathrm{Mg}^{2+}$ block was associated with a mild reduction of the $\mathrm{Zn}^{2+}$ block (see also Kawajiri and Dingledine, 1993), probably because the mutations reduced or abolished the $\mathrm{Zn}^{2+}$ voltage-dependent block but left intact the $\mathrm{Zn}^{2+}$ voltageindependent inhibition.

The present study aimed at a better separation of the voltagedependent and the voltage-independent processes in recombinant receptors. In attempting to measure the inhibitory effect of $\mathrm{Zn}^{2+}$ on NR1a-NR2A receptors expressed in Xenopus oocytes and human embryonic kidney (HEK) cells, we observed inhibitions of very variable size at concentrations of a few tens of nanomolars. This was found to be attributable to the variable degree of contamination of the solutions by traces of heavy metal ions (possibly $\mathrm{Zn}^{2+}$ ). By using chelators of these metals, we were able to obtain a reliable estimate of the control response and to demonstrate that the $\mathrm{IC}_{50}$ of the voltage-independent $\mathrm{Zn}^{2+}$ inhibition is highly subunit-specific, ranging from $\sim 10 \mathrm{nM}$ in the case of NR1a-NR2A receptors to $10 \mu \mathrm{M}$ in NR1a-NR2C receptors. In contrast, the voltage-dependent $\mathrm{Zn}^{2+}$ inhibition has an $\mathrm{IC}_{50}$ in the micromolar range in NR1a-NR2A receptors and can be suppressed selectively by a point mutation in the pore region [NR2A(N595K)].

\section{MATERIALS AND METHODS}

\section{Primary neuronal cultures}

Cortical and diencephalic neurons taken from 15- to 16-d-old mouse embryos were cultured for 2-5 weeks, as previously described by Ascher et al. (1988). 
NMDA receptor expression in HEK cells and Xenopus oocytes Plasmid constructions. All of the cDNAs used in this study were subcloned in a modified (see Kupper et al., 1996) pcDNA3 vector (Invitrogen, Leek, Netherlands), allowing high-level expression of recombinant proteins in transfected mammalian cells as well as in Xenopus oocytes after nuclear injection. The subunit cDNAs were subcloned from the following pBluescript-based plasmids: pN60 [Moriyoshi et al. (1991); gift from S. Nakanishi, Kyoto University, Japan] for NR1a, pNMDAR1-1b [Hollmann et al. (1993); gift from J. Boulter, Salk Institute, La Jolla, CA], NR2A and NR2C [Monyer et al. (1992); gift from P. Seeburg, Center for Molecular Biology, Heidelberg, Germany], and $\epsilon 2$ [Kutsuwada et al. (1992); gift from M. Mishina, Niigata University, Japan] for NR2B. The plasmid coding for the green fluorescent protein (GFP) (Chalfie et al., 1994) was a gift from D. Pritchett.

Site-directed mutagenesis. Site-directed mutagenesis was performed according to a method modified from Kunkel (1985). The presence of the mutation was verified by sequencing across the M2 region with the Sequenase Kit (Stratagene Cloning Systems, La Jolla, CA).

Transfection of HEK cells. HEK cells were cultured in a DMEM medium (with L-glutamine and $4.5 \mathrm{gm} / 1$ glucose added) containing $10 \%$ heat-inactivated fetal calf serum and penicillin-streptomycin $(5000$ $\mathrm{U} / \mathrm{ml}$ ). Low confluency cells were transfected by the calcium phosphate precipitation method (Chen and Okayama, 1987). Cells were cotransfected with a mixture containing NR1, NR2, and GFP plasmids $(0.3,0.9$, and $0.8 \mu \mathrm{g}$ per $35 \mathrm{~mm}$ diameter dish, respectively). After transfection, $100 \mu \mathrm{M}$ D-AP5 was added to the culture medium.

Expression of NMDA receptors in Xenopus oocytes. Preparation of oocytes and nuclear injection of cDNAs coding for wild-type and mutant NMDA receptors were performed as described by Paoletti et al. (1995).

\section{Chemicals}

NMDA and D-2-amino-5-phosphopentanoic acid (D-AP5) were obtained from Tocris Cookson (Bristol, UK). Glycine, L-glutamate, zinc chloride, HEPES, $N$-tris(hydroxymethyl)methylglycine (tricine), diethylenetriaminepentaacetic acid (DTPA), EDTA, $N, N, N^{\prime}, N^{\prime}$-tetrakis-(2-pyridylmethyl)ethylenediamine (TPEN), $N$-(2-acetamido)iminodiacetic acid (ADA), and dithioerythritol (DTE) were obtained from Sigma (Saint Quentin Fallavier, France). All other salts were obtained from Prolabo (Paris, France) and were of "Normapur" grade. Zinc chloride stock solutions (10 $\mu \mathrm{M}-100 \mathrm{mM})$ were prepared by progressive dilutions with bidistilled water of a solution containing $100 \mathrm{mM} \mathrm{ZnCl}_{2}$ and $10 \mathrm{mM} \mathrm{HCl}$. The stock solution of TPEN (50 mM) was prepared in $\sim 100 \mathrm{~mm} \mathrm{HCl}$. Other stock solutions (EDTA, $250 \mathrm{~mm}$; DTE, $300 \mathrm{~mm}$; tricine, $1 \mathrm{M}$; DTPA, $300 \mathrm{~mm}$; ADA, $500 \mathrm{~mm}$ ) were prepared in bidistilled water, and their $\mathrm{pH}$ was adjusted to 7.4 with $\mathrm{NaOH}$.

\section{Buffered $\mathrm{Zn}^{2+}$ solutions}

The marked effects of heavy metal chelators on the response of NR1aNR2A NMDA receptors (see Fig. 1, Table 1) and the apparent high affinity of these receptors for $\mathrm{Zn}^{2+}$ (see Fig. $3 B$ ) required the use of buffered $\mathrm{Zn}^{2+}$ solutions to establish $\mathrm{Zn}^{2+}$ inhibition curves. The heavy metal chelators tested in this study have a very high affinity for $\mathrm{Zn}^{2+}\left(K_{\mathrm{D}}\right.$ $<10^{-10}$ M; see Table 1), which precludes their use to buffer $\mathrm{Zn}^{2+}$ in the $1-100 \mathrm{~nm}$ range. In this respect, tricine, with a $K_{\mathrm{D}}$ of $10^{-7.3} \mathrm{M}$ (Dawson et al., 1986), seemed more promising. We used MaxChel, a program for buffer calculations [which takes into account the $\mathrm{pH}$ and the ionic strength of the solutions (Bers et al., 1994)] with the published binding constants of tricine, to prepare buffered solutions for $\mathrm{Zn}^{2+}$ in the $10-100$ nM range. We expected that the responses recorded with NR1a-NR2A receptors with such solutions would be smaller than the responses recorded in $\mathrm{Zn}^{2+}$-free solutions but larger than the responses recorded in nonbuffered solutions to which $100 \mathrm{nM} \mathrm{Zn}^{2+}$ had been added. The actual responses were much smaller than predicted, which suggested that we had used incorrect binding constants for tricine. To estimate more accurate values for these constants, we took advantage of the fact that at concentrations of a few micromolars $\mathrm{Zn}^{2+}$ produces a voltage-dependent inhibition. From the amount of $\mathrm{Zn}^{2+}$ voltage-dependent block we estimated the free $\mathrm{Zn}^{2+}$ concentration in our buffered solutions and hence calculated an empirical $K_{\mathrm{D}}$ of tricine for $\mathrm{Zn}^{2+}$ in our experimental conditions of $10^{-5} \mathrm{M}$ instead of $10^{-7.3} \mathrm{M}$. The buffered $\mathrm{Zn}^{2+}$ solutions used to obtain the $\mathrm{Zn}^{2+}$ dose-response curves shown in Figures $2 A$ and $3 A$ were prepared according to this empirically established binding constant by adding to $10 \mathrm{~mm}$ tricine the following concentrations of $\mathrm{Zn}^{2+}$ (in $\mu \mathrm{M}$ ): $0.26,0.78,2.6,7.8,26,77.5$, and 254 . The corresponding estimated concentrations of free $\mathrm{Zn}^{2+}$ were (in nM): $1,3,10,30,100,300$, and 1000 , respectively. Note that in the calculations for the buffered solutions the weak $\mathrm{Zn}^{2+}$ chelation properties of glycine and glutamate (Dawson et al., 1986) have been neglected.

\section{Recording conditions}

Neurons and HEK cells. Experiments on native neuronal receptors were performed on nucleated patches (see Sather et al., 1992). GFP-positive HEK cells were used for electrophysiological recordings 16-48 hr after transfection in the whole-cell patch-clamp configuration (Hamill et al., 1981). In all recordings HEK cells were lifted off the chamber floor to permit rapid solution changes. Soft glass patch pipettes of 3-5 $\mathrm{M} \Omega$ were filled with a solution containing (in mM): $120 \mathrm{CsF}, 10 \mathrm{CsCl}, 10$ EGTA, and 10 HEPES, pH-adjusted to 7.2 with $\mathrm{CsOH}$.

The standard external solution (control solution) contained (in mM): 140 $\mathrm{NaCl}, 2.8 \mathrm{KCl}, 1 \mathrm{CaCl}_{2}$, and $10 \mathrm{HEPES}, \mathrm{pH}$-adjusted to 7.3 with $\mathrm{NaOH}$. Drugs and agonists were applied to the patch by means of an eight-barrel fast-perfusion system (Sather et al., 1992). Solutions flowed continuously by gravity from all barrels. In all whole-cell and nucleated-patch experiments, glutamate (HEK cells) or NMDA (neurons) was applied on a continuous background of glycine. NMDA was used at $200 \mu \mathrm{M}$. Glutamate and glycine were each present at a saturating concentration $(100 \mu \mathrm{M})$.

Xenopus oocytes. Two-electrode voltage-clamp recordings were made 1-7 d after cDNA injection, using low resistance (0.5-1.5 M $\Omega$ ) electrodes filled with $3 \mathrm{M} \mathrm{KCl}$. The standard solution superfusing the oocytes contained (in mM): $100 \mathrm{NaCl}, 2.8 \mathrm{KCl}, 5$ HEPES, and $0.3 \mathrm{BaCl}_{2}$, $\mathrm{pH}$-adjusted to 7.3 with $\mathrm{NaOH}$. The low external $\mathrm{Ba}^{2+}$ concentration was used to minimize $\mathrm{Ba}^{2+}$ entry via NMDA channels and the subsequent activation of $\mathrm{Ca}^{2+}$-dependent conductances (Leonard and Kelso, 1990). The volume of the bath in the recording chamber was $\sim 100 \mu$ l. The rate of perfusion $(\sim 4 \mathrm{ml} / \mathrm{min})$ allowed a complete exchange of the solutions in $2-5$ sec. Glycine $(100 \mu \mathrm{M})$ and L-glutamate $(100 \mu \mathrm{M})$ were applied simultaneously, usually for $10 \mathrm{sec}$ every $2 \mathrm{~min}$, using motor-driven valves. When the $\mathrm{Zn}^{2+}$ concentration was varied, currents were recorded after $30-60 \mathrm{sec}$ of preincubation at the test $\mathrm{Zn}^{2+}$ concentration. The response at each test $\mathrm{Zn}^{2+}$ concentration usually was compared with the control responses (no added $\mathrm{Zn}^{2+}$ or " 0 " $\mathrm{Zn}^{2+}$; see Results) before and after the change in $\mathrm{Zn}^{2+}$ concentration.

All experiments were performed at room temperature $\left(18-25^{\circ} \mathrm{C}\right)$.

\section{Recording and data analysis}

In neurons and HEK cells currents were recorded with a List EPC-7 amplifier (Darmstadt, Germany) and a Racal FM tape recorder. The voltage-clamp current usually was filtered (8-pole Bessel) with a corner frequency of $250 \mathrm{~Hz}$, sampled at twice this frequency, and later analyzed by Strathclyde Electrophysiology Software (gift from John Dempster, Strathclyde University, Glasgow, Scotland). For whole-cell recordings the series resistance $(3-8 \mathrm{M} \Omega$ ) was partially compensated (50-90\%) and monitored throughout the experiment.

Currents from oocytes were recorded with a Warner Instrument OC725 amplifier (Hamden, CT). After being filtered at $500 \mathrm{~Hz}$, traces were acquired at $250 \mathrm{~Hz}$ with pClamp V6.0 (Axon Instruments, Foster City, CA). Current-voltage curves were obtained with slow voltage ramps (2 sec duration) from -100 or -70 to $+50 \mathrm{mV}$ (the capacitive and leakage currents were recorded before agonist application and substracted from the glutamate-induced current traces).

For $\mathrm{Zn}^{2+}$ dose-response curves the response at each tested $\mathrm{Zn}^{2+}$ concentration was bracketed by two responses in a $\mathrm{Zn}^{2+}$-free solution (in the presence of a $\mathrm{Zn}^{2+}$ chelator, usually $1 \mu \mathrm{M}$ TPEN) and then compared with the mean of these two $\mathrm{Zn}^{2+}$-free responses. In the analysis of the $\mathrm{Zn}^{2+}$ voltage-dependent block the "unblocked fraction" curves (Fig. $5 B$ ) were obtained by dividing the current-voltage curve obtained at each tested $\mathrm{Zn}^{2+}$ concentration by the current-voltage curve obtained in a $\mathrm{Zn}^{2+}$-free solution (in these experiments TPEN, which induces a moderate voltage-dependent block of the glutamate response at potentials below $-80 \mathrm{mV}$, was replaced by another $\mathrm{Zn}^{2+}$ chelator, DTPA, which showed no detectable voltage-dependent inhibitory effects in the range from -150 to $+100 \mathrm{mV}$ ). We assumed that the $\mathrm{Zn}^{2+}$ voltage-dependent block was relieved completely at $+50 \mathrm{mV}$ and therefore normalized all unblocked fraction curves to 1 at $+50 \mathrm{mV}$. The unblocked fraction values at $0 \mathrm{mV}$ could not be evaluated directly from the data (close to the reversal potential, the ratios of the current traces take artifactual infinite values). They were calculated by using polynomial fits to the data collected outside the -10 to $+10 \mathrm{mV}$ range.

Unless otherwise specified, error bars represent SD. 
HEK 293 cells

A

control

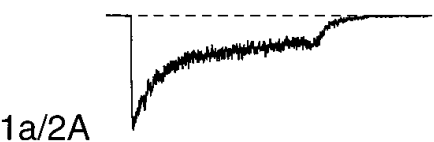

B control

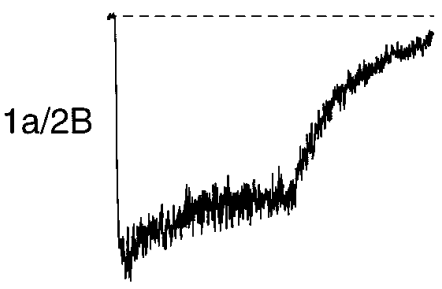

$1 \mu \mathrm{M}$ TPEN

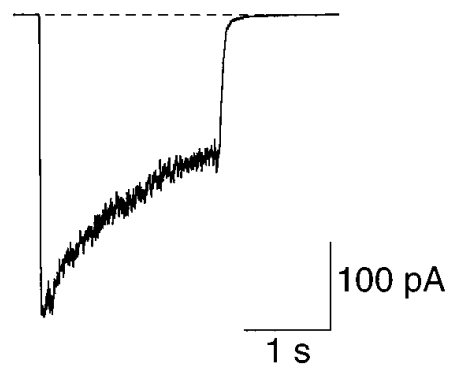

$1 \mu \mathrm{M}$ TPEN

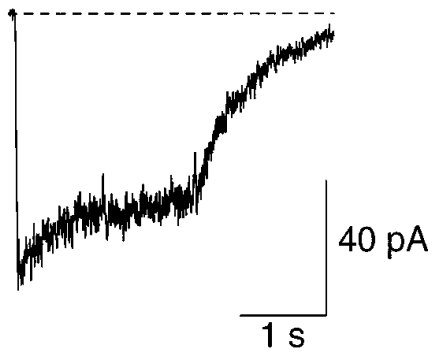

Xenopus oocytes

C

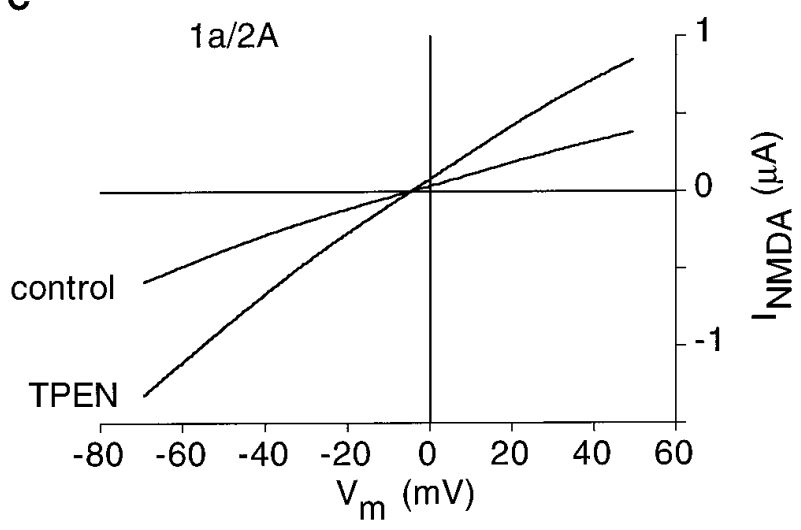

D

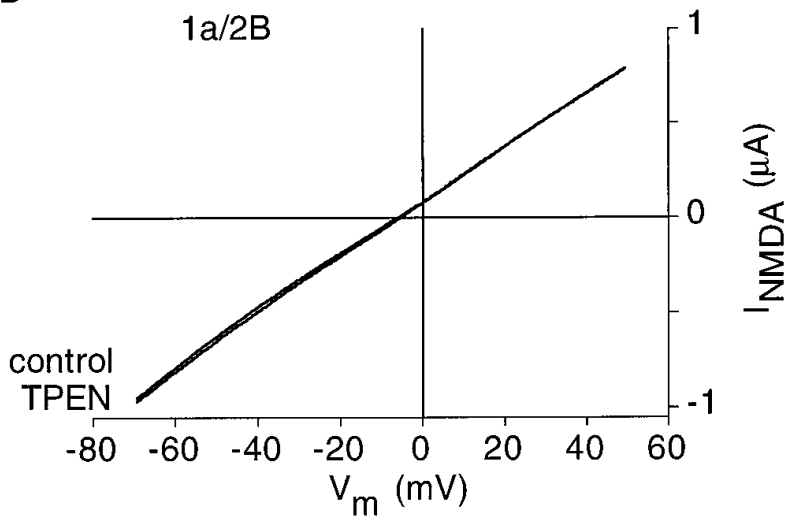

Figure 1. NR1a-NR2A responses are potentiated by the heavy metal chelator TPEN. Recombinant NMDA receptors expressed in HEK 293 cells $(A$, $B)$ or in Xenopus oocytes $(C, D)$ were activated by applying saturating concentrations of glutamate $(100 \mu \mathrm{M})$ and glycine $(100 \mu \mathrm{M})$. The responses were compared before (control) and after (TPEN) addition of $1 \mu \mathrm{M}$ TPEN to the external solution. $A, B$, HEK cells. Glutamate was applied on a background of glycine for $2 \mathrm{sec}$ every $10 \mathrm{sec}$ on cells held at $-50 \mathrm{mV}$. The external $\mathrm{Ca}^{2+}$ concentration was $1 \mathrm{~mm}$. $A$, TPEN potentiates NR1a-NR2A responses. Each trace is the average of five records. $B, \mathrm{NR} 1 \mathrm{a}-\mathrm{NR} 2 \mathrm{~B}$ responses are not affected by $1 \mu \mathrm{M}$ TPEN. Each trace is the average of fifteen records. $C, D$, Xenopus oocytes. Voltage ramps from -70 to $+50 \mathrm{mV}$ were applied in the absence (control) or presence of $1 \mu \mathrm{M}$ TPEN. Current-voltage curves corresponding to the leak currents were substracted from those obtained during steady applications of $100 \mu \mathrm{M}$ glutamate and $100 \mu \mathrm{M}$ glycine. The only external divalent cation was $\mathrm{Ba}^{2+}(0.3 \mathrm{~mm})$. $C$, TPEN potentiates NR1a-NR2A responses over the whole voltage range. $D$, NR1a-NR2B currents recorded in the absence or in the presence of TPEN are superimposed.

\section{RESULTS}

\section{Heavy metal chelators potentiate NMDA NR1a-NR2A receptor activity}

Recombinant NMDA receptors were expressed both in HEK cells and Xenopus oocytes. Responses were elicited by applying saturating concentrations of both glycine $(100 \mu \mathrm{M})$ and glutamate $(100 \mu \mathrm{M})$. As shown in Figure 1A, NR1a-NR2A whole-cell currents recorded at $-50 \mathrm{mV}$ in $\mathrm{HEK}$ cells were enhanced markedly ( $\sim$ threefold increase in the peak current) by the addition of a low concentration $(1 \mu \mathrm{M})$ of TPEN, a highly specific heavy metal chelating agent (see Table 1; Arslan et al., 1985). This potentiation was rapid and fully reversible. When glutamate pulses were applied at $10 \mathrm{sec}$ intervals, the potentiation was already maximal for the response to the first pulse applied after the addition of TPEN. Similarly, a complete recovery was observed for the response to the first pulse applied in the TPEN-free solution (data not shown). Unlike NR1a-NR2A responses, NR1a-NR2B responses recorded in the same conditions were not affected by TPEN (Fig. 1B).
Similar results were obtained for NMDA receptors expressed in Xenopus oocytes. Figure $1, C$ and $D$, shows leak-substracted NMDA currents recorded during voltage ramps applied in oocytes expressing either NR1a-NR2A receptors (Fig. 1C) or NR1aNR2B receptors (Fig. 1D). Whereas TPEN $(1 \mu \mathrm{M})$ had no effect on the NR1a-NR2B current, it induced an approximately twofold potentiation of the NR1a-NR2A current. Moreover, as illustrated in Figure $1 C$, the potentiation of NR1a-NR2A currents produced by the addition of TPEN was voltage-independent.

The ratio of the peak current recorded at $-50 \mathrm{mV}$ in the presence of TPEN over the peak current recorded in the absence of TPEN was close to 1 for NR1a-NR2B receptors expressed in HEK cells $(1.07 \pm 0.04 ; n=6)$ or oocytes $(1.03 \pm 0.02 ; n=10)$, whereas for NR1a-NR2A receptors the mean ratio was $2.9 \pm 0.3$ $(n=6)$ in HEK cells and slightly lower in oocytes $(2.05 \pm 0.6$; $n=17)$.

These results suggested that TPEN removes from the external medium a metal that tonically inhibits NR1a-NR2A, but not NR1a-NR2B, receptors. Because the effect is seen with a con- 


\begin{tabular}{llllll}
\hline \multicolumn{6}{l}{ Table 1. Potentiation of NMDA NR1a-NR2A receptors by heavy metal chelators } \\
& $\begin{array}{l}\text { TPEN } \\
(1 \mu \mathrm{M})\end{array}$ & $\begin{array}{l}\text { EDTA } \\
(10 \mu \mathrm{M})\end{array}$ & $\begin{array}{l}\text { DTPA } \\
(2 \mu \mathrm{M})\end{array}$ & $\begin{array}{l}\text { ADA } \\
(100 \mu \mathrm{M})\end{array}$ & $\begin{array}{l}\text { Tricine } \\
(10 \mathrm{mM})\end{array}$ \\
\hline$K_{\mathrm{D} \mathrm{Zn}}{ }^{2+}(\mathrm{M})^{a}$ & $10^{-15.6}$ & $10^{-16.4}$ & $10^{-18.7}$ & $10^{-9.7}$ & $10^{-5.0}$ \\
$1 \mathrm{a} / 2 \mathrm{~A}^{b}$ & $1.6 \pm 0.1$ & $\begin{array}{l}1.7 \pm 0.1 \\
(n=8)\end{array}$ & $\begin{array}{l}1.7 \pm 0.1 \\
(n=6)\end{array}$ & $\begin{array}{l}1.6 \pm 0.1 \\
(n=6)\end{array}$ & $\begin{array}{l}1.7 \pm 0.1 \\
(n=6)\end{array}$ \\
$1 \mathrm{a} / 2 \mathrm{~B}^{b}$ & $\begin{array}{l}(n=5) \\
1.03 \pm 0.02\end{array}$ & & & &
\end{tabular}

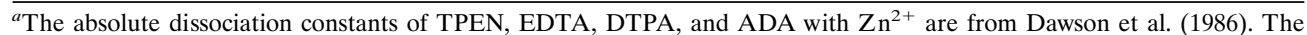
dissociation constant of tricine with $\mathrm{Zn}^{2+}$ was estimated as described in Materials and Methods.

${ }^{b}$ Each value represents the mean current ratio (heavy metal chelator/control). To minimize the variations in the amount of contaminant heavy metal traces from one experiment to the other, we performed all of the experiments with NR1a-NR2A receptors used in this table on the same day, with the addition of the different chelators to the same control external solution. Recombinant NMDA receptors were expressed in Xenopus oocytes. The external $\mathrm{Ba}^{2+}$ concentration was $0.3 \mathrm{~mm}$, and the external $\mathrm{pH}$ was 7.3 . The holding potential was $-60 \mathrm{mV}$.
\end{abstract}

centration of chelator as low as $1 \mu \mathrm{M}$, one can exclude effects involving the divalent cations $\mathrm{Ca}^{2+}$ or $\mathrm{Ba}^{2+}$ present in the extracellular solutions at millimolar concentrations, and one might suspect the involvement of a heavy metal such as $\mathrm{Zn}^{2+}$ or $\mathrm{Cu}^{2+}$.

In both expression systems the magnitude of the potentiation of the NR1a-NR2A responses was quite variable, ranging in oocytes from 1.5 to 3.7 and from 2.5 to 3.3 in $\mathrm{HEK}$ cells (for $\mathrm{HEK}$ cells, see Fig. $7 A$ ). A likely explanation of this variability is that the putative heavy metal removed by TPEN is present in the external solutions at concentrations varying from one experiment to the other.

TPEN was chosen initially for its powerful heavy metal chelating properties and its poor $\mathrm{Ca}^{2+}$ affinity (Arslan et al., 1985). However, it has been shown that TPEN permeates readily biological membranes (Arslan et al., 1985), and the possibility had to be considered that external TPEN enters the cell and potentiates NR1a-NR2A responses via an intracellular mechanism. To evaluate this hypothesis, we tested the effects of three membraneimpermeant heavy metal chelators: EDTA, DTPA, and ADA (see Table 1; Dawson et al., 1986). The experiments were performed in oocytes in the presence of $0.3 \mathrm{~mm} \mathrm{Ba}^{2+}$. As shown in Table 1, each of the three compounds potentiated NR1a-NR2A responses recorded at negative potentials. Moreover, the potentiations produced by each chelator were very similar to the potentiation produced by TPEN. This result argues against an intracellular mechanism of action of TPEN and suggests that the four compounds act by complexing a contaminant heavy metal present in the external solution at a concentration high enough to inhibit $\mathrm{NR} 1 \mathrm{a}-\mathrm{NR} 2 \mathrm{~A}$ responses. Candidates for trace impurity are numerous, including $\mathrm{Zn}^{2+}, \mathrm{Cd}^{2+}, \mathrm{Mn}^{2+}, \mathrm{Cu}^{2+}, \mathrm{Fe}^{2+}$, and $\mathrm{Al}^{3+}$.

\section{$\mathrm{Zn}^{2+}$ inhibits NR1a-NR2A responses in the nanomolar range}

The effects of various heavy metals on NMDA receptors have been studied in many neuronal preparations (Mayer et al., 1989; Eimerl and Schramm, 1993; Trombley and Shepherd, 1996; Vlachova et al., 1996). These studies have shown that $\mathrm{Zn}^{2+}, \mathrm{Cd}^{2+}$, $\mathrm{Fe}^{2+}$, and $\mathrm{Cu}^{2+}$ are NMDA antagonists, among which $\mathrm{Zn}^{2+}$ is the most potent, inhibiting native NMDA receptor activity at concentrations of a few micromolars. However, in all of these experiments the possible presence in the external solutions of endogenous $\mathrm{Zn}^{2+}$ (and of other heavy metals) was not taken into account, and the solutions with no added $\mathrm{Zn}^{2+}$ were assumed to be $\mathrm{Zn}^{2+}$-free. The observation that heavy metal chelating agents potentiate NMDA NR1a-NR2A responses, by suggesting that
$\mathrm{Zn}^{2+}$ could be present as an endogenous metal in the external solutions at a submicromolar concentration (necessarily lower than that of the chelator producing a large potentiation), imposed a reevaluation of the inhibitory constants deduced from early work.

To evaluate the potency of $\mathrm{Zn}^{2+}$ as a high-affinity NMDA receptor antagonist, we used three different protocols. The first two involved the construction in oocytes of dose-response curves either with or without buffered $\mathrm{Zn}^{2+}$ solutions. The third approach was based on the measurement in HEK cells of the current relaxations after step changes in $\mathrm{Zn}^{2+}$ concentrations.

To use buffered $\mathrm{Zn}^{2+}$ solutions, we looked for a chelating agent capable of producing buffered free $\mathrm{Zn}^{2+}$ concentrations in the nanomolar to micromolar range. For this purpose the binding constants of TPEN, EDTA, DTPA, and ADA with $\mathrm{Zn}^{2+}$ were much too high (absolute $K_{\mathrm{D}} \leq 10^{-9.7} \mathrm{M}$; Table 1 ), so we selected tricine, which binds $\mathrm{Zn}^{2+}$ with a low affinity (we estimated the absolute $K_{\mathrm{D}}$ as $10^{-5} \mathrm{M}$; see Materials and Methods), but has an even lower affinity for $\mathrm{Ca}^{2+}$ or $\mathrm{Ba}^{2+}$ (absolute $K_{\mathrm{D}} \sim 100 \mathrm{~mm}$ ) present in the external solutions at millimolar concentrations. We first compared, on NR1a-NR2A receptors expressed in oocytes, the effect of tricine with that of the other chelating agents used previously. Tricine $(10 \mathrm{~mm})$ potentiated NR1a-NR2A responses by the same amount as TPEN, EDTA, DTPA, and ADA (see Table 1). In what follows, " 0 " $\mathrm{Zn}^{2+}$ solution refers to a solution with no added $\mathrm{Zn}^{2+}$ but containing one of the five chelating agents.

We then tested the effects of various $\mathrm{Zn}^{2+}$ concentrations in tricine-buffered solutions on NR1a-NR2A receptors and found that they revealed two inhibitory effects differing markedly in their $\mathrm{IC}_{50}$ values and voltage dependence. The first is illustrated in Figure $2 A$, which shows the inhibition produced by $\mathrm{Zn}^{2+}$ at concentrations from $3 \mathrm{nM}$ to $1 \mu \mathrm{M}$. The reduction of the conductance is very similar over the whole potential range tested. An estimated concentration of $3 \mathrm{nM}$ free $\mathrm{Zn}^{2+}$ is sufficient to produce a clear inhibition; the response is reduced by more than one-half at an estimated concentration of $30 \mathrm{~nm}$ free $\mathrm{Zn}^{2+}$ and by nearly $80 \%$ at $1 \mu \mathrm{M} \mathrm{Zn}^{2+}$. Figure $2 B$ shows that for concentrations of $\mathrm{Zn}^{2+}$ above $1 \mu \mathrm{M}$ (at these concentrations there is no noticeable difference between buffered and nonbuffered solutions) the pattern of inhibition changes. There is nearly no additional inhibition in the positive potential range, suggesting that the voltage-independent inhibition has reached its maximum; on the other hand, in the negative potential range the inhibition 
A

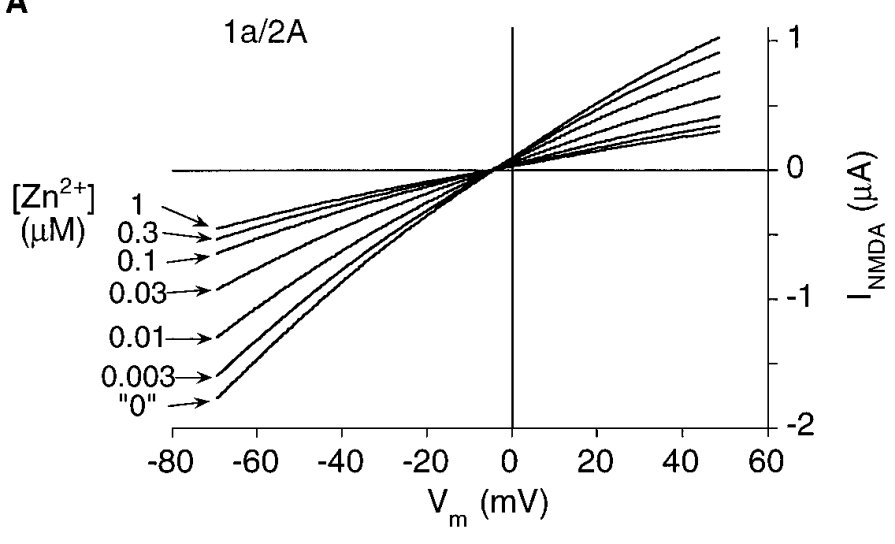

B

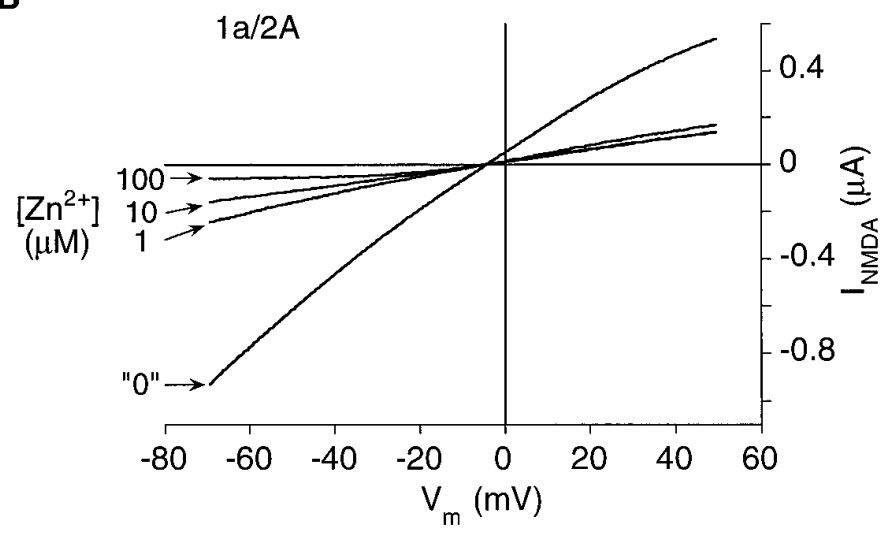

C
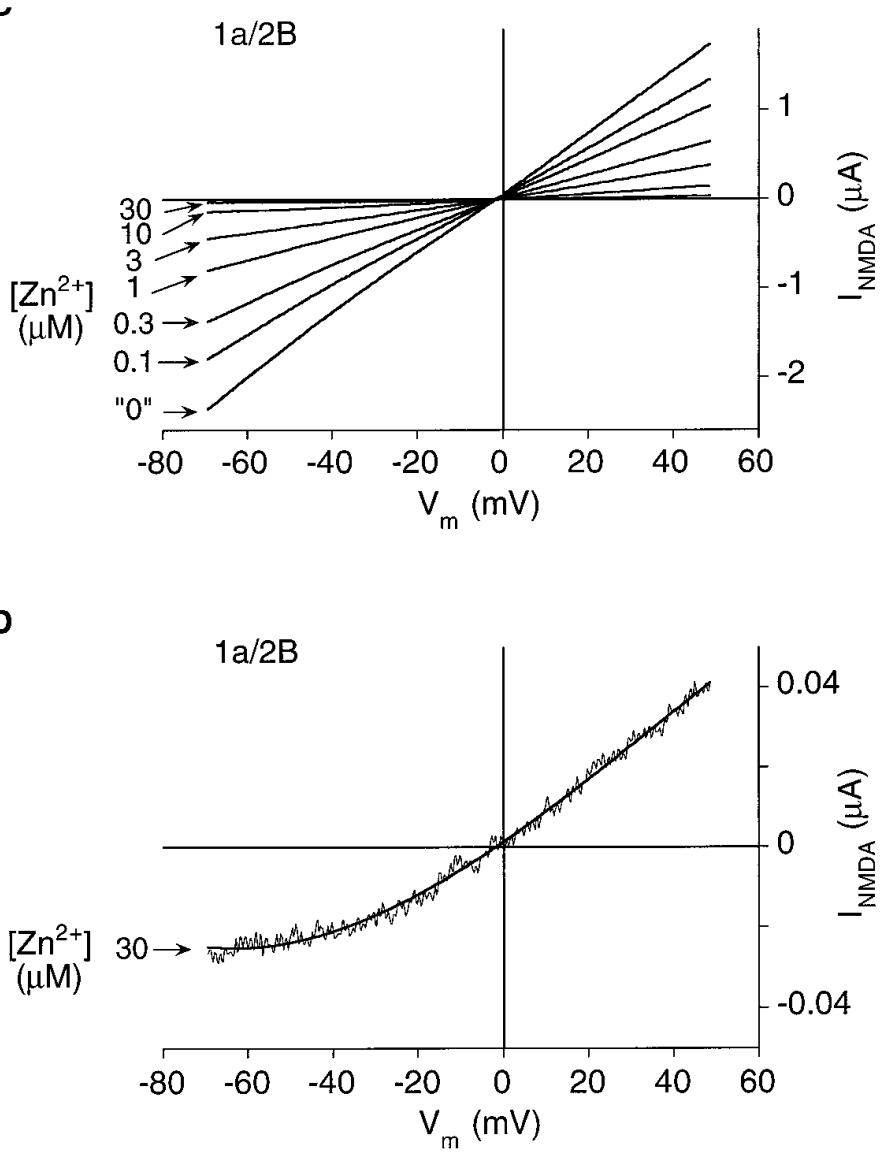

Figure 2. Nanomolar external $\mathrm{Zn}^{2+}$ concentrations selectively inhibit NR1a-NR2A responses. Leak-substracted NMDA currents were recorded at different concentrations of external $\mathrm{Zn}^{2+}$ during voltage ramps from -70 to $+50 \mathrm{mV}$ applied in Xenopus oocytes expressing NR1a-NR2A or NR1a-NR2B receptors. Glutamate and glycine were applied at saturating concentrations (100 $\mu \mathrm{M}$ each). The " 0 " $\mathrm{Zn}{ }^{2+}$ concentration refers to a solution containing a $\mathrm{Zn}^{2+}$ chelator with no added $\mathrm{Zn}^{2+}$ (see Results). $A$, NR1a-NR2A responses are inhibited by $\mathrm{Zn}^{2+}$ concentrations of a few nanomolars. The inhibition is voltage-independent. At higher $\mathrm{Zn}^{2+}$ concentrations the inhibition saturates at $\sim 75 \%$ of the response in the " 0 " solution. The indicated $\mathrm{Zn}^{2+}$ concentrations correspond to calculated free $\mathrm{Zn}^{2+}$ concentrations in solutions buffered with 10 mm tricine (see Materials and Methods). The " 0 " solution contained $10 \mathrm{~mm}$ tricine and no added $\mathrm{Zn}^{2+} . B$, An additional voltage-dependent inhibition is produced by micromolar concentrations of $\mathrm{Zn}^{2+}$. The responses are from a different oocyte. The indicated $\mathrm{Zn}^{2+}$ concentrations correspond to nominal values. The " 0 " $\mathrm{Zn}{ }^{2+}$ solution contained $1 \mu \mathrm{M}$ TPEN. $C, \mathrm{Zn}^{2+}$ antagonism of NR1a-NR2B responses is of lower affinity, is total, and is mainly voltage-independent. The indicated $\mathrm{Zn}{ }^{2+}$ concentrations correspond to nominal values. The " 0 " $\mathrm{Zn}^{2+}$ solution contained $1 \mu \mathrm{M}$ TPEN. $D$, Expanding the current scale at a high $\mathrm{Zn}{ }^{2+}$ concentration $(30 \mu \mathrm{M})$ reveals a voltage-dependent component of the inhibition of NR1a-NR2B responses. Shown is the same cell as in $C$. For clarity, the data were fit with a third-order polynomial.

continues to increase with the $\mathrm{Zn}^{2+}$ concentration and the more so at more negative potentials.

These results indicate that $\mathrm{Zn}^{2+}$ exerts a dual block on NMDA NR1a-NR2A receptors: one is voltage-independent and seen with nanomolar concentrations of $\mathrm{Zn}^{2+}$; the other is voltagedependent and requires much higher $\mathrm{Zn}^{2+}$ concentrations (in the micromolar range). At $-60 \mathrm{mV}$ the dose-response curve obtained with tricine-buffered solutions was well fit with a twobinding-site isotherm, using $\mathrm{IC}_{50}$ values of $17 \mathrm{nM}$ and $26 \mu \mathrm{M}$ having relative weights of 75 and $25 \%$, respectively (Fig. 3A). Qualitatively, these results are reminiscent of the actions of $\mathrm{Zn}^{2+}$ described on native NMDA receptors (Christine and Choi, 1990; Legendre and Westbrook, 1990), but quantitatively the affinity of the site involved in the voltage-independent process appears to be three orders of magnitude higher than reported on native NMDA receptors.

Dose-response curves obtained by applying $\mathrm{Zn}^{2+}$ in nonbuffered solutions (nominal $\mathrm{Zn}^{2+}$ concentrations) resembled those obtained with buffered solutions and showed two well separated regions of inhibition at negative potentials. However, as expected from the presence of contaminating traces of $\mathrm{Zn}^{2+}$ (or another compound) in the control solutions, the points obtained at low $\mathrm{Zn}^{2+}$ concentrations were poorly fit by a standard isotherm (data not shown). The fit was improved greatly by adding to the nominal $\mathrm{Zn}^{2+}$ concentrations an assumed contaminating $\mathrm{Zn}^{2+}$ concentration. As shown in Figure $3 B$, at $-60 \mathrm{mV}$ a satisfactory fit could be obtained by assuming a contaminating level of $\mathrm{Zn}^{2+}$ of $10 \mathrm{~nm}$. This correction led to $\mathrm{IC}_{50}$ values $(6 \mathrm{~nm}$ and $32 \mu \mathrm{M})$ and to the relative weight of the two effects (78 and $22 \%$ ), which were very similar to those found with tricine-buffered solutions (see above). Moreover, at positive potentials (e.g., at $+50 \mathrm{mV}$ ), only the high-affinity $\mathrm{Zn}^{2+}$ inhibition was present. Its $\mathrm{IC}_{50}(5 \mathrm{nM})$ was identical to that calculated at $-60 \mathrm{mV}$, and it saturated at $\sim 20 \%$ of the maximal current (Fig. $3 D$ ).

In contrast to NR1a-NR2A responses, NR1a-NR2B responses were not affected by heavy metal chelators. This suggested that, if $\mathrm{Zn}^{2+}$ inhibits NR1a-NR2B receptors, the inhibition must be of lower affinity than that of NR1a-NR2A receptors. 
A

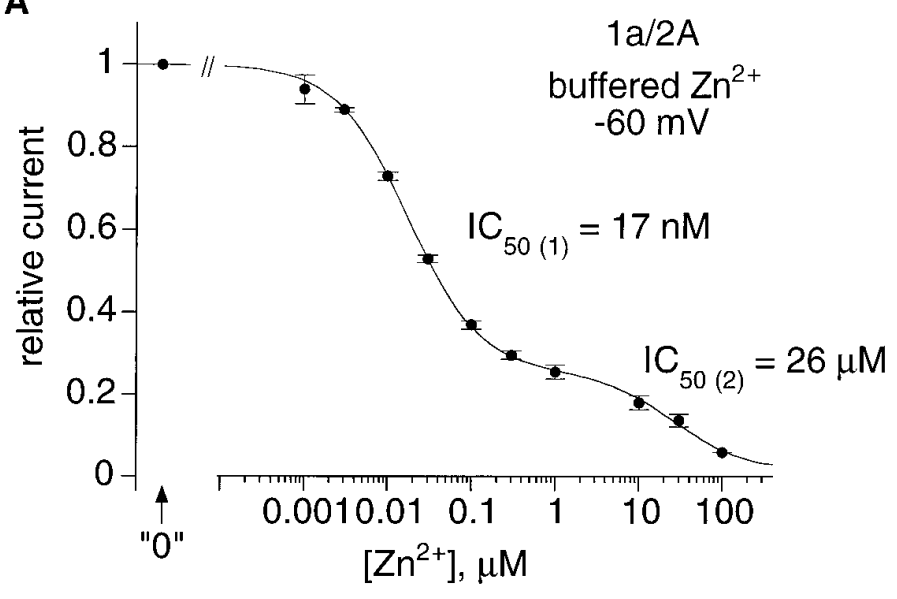

B

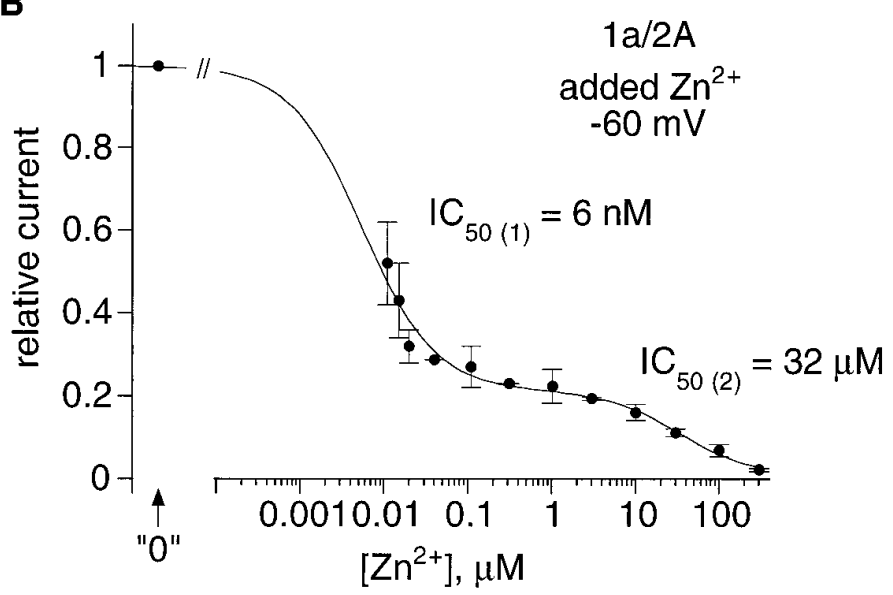

C

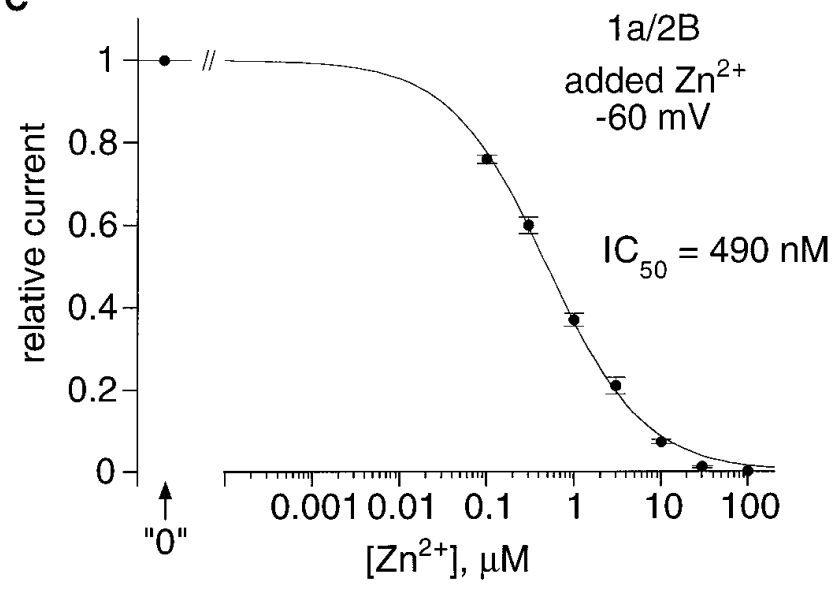

D

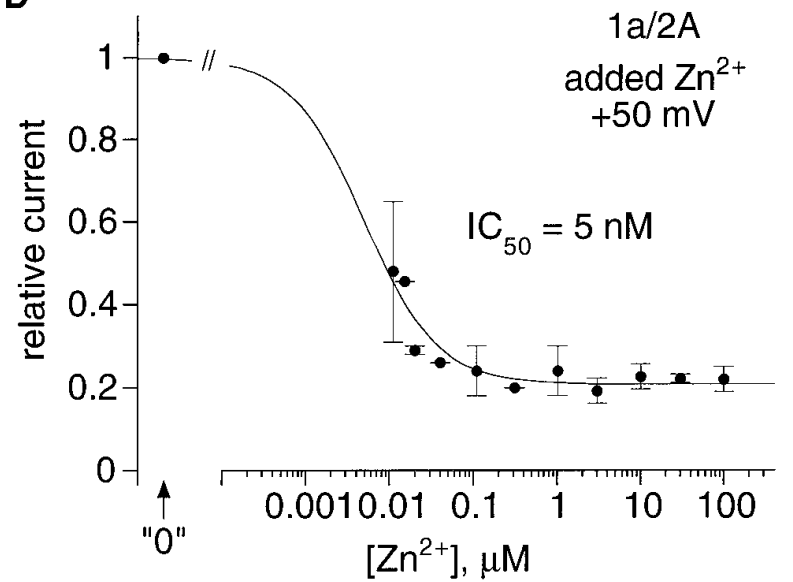

Figure 3. Concentration dependence of the $\mathrm{Zn}^{2+}$ inhibition of NR1a-NR2A and NR1a-NR2B receptors. Recombinant NMDA receptors were expressed in Xenopus oocytes, and dose-response curves were constructed from $I-V$ curves obtained as in Figure 2 . In each experiment currents were expressed as a fraction of the current recorded in the presence of a $\mathrm{Zn}^{2+}$ chelator ( " 0 " $\mathrm{Zn}^{2+}$ ). The curves in $A$ and $B$ represent least-squares fits to the data points with the two-binding-site isotherm $y=1-\left(\left(a /\left(1+\mathrm{IC}_{50(1)} /\left[\mathrm{Zn}^{2+}\right]\right)\right)+\left(b /\left(1+\mathrm{IC}_{50(2)} /\left[\mathrm{Zn}^{2+}\right]\right)\right)\right)$, in which $y$ is the relative current, and $a$ and $b$ are the respective weights of each isotherm. The curves in $C$ and $D$ represent least-squares fits to the data points with the single-binding-site isotherm $y=1-\left(a /\left(1+\left(\mathrm{IC}_{50} /\left[\mathrm{Zn}^{2+}\right]\right)^{n}\right)\right)$, in which $y$ is the relative current, $n$ is the Hill coefficient, and $a$ is a weight factor. $A, B$, Dual antagonism by $\mathrm{Zn}^{2+}$ of NR1a-NR2A responses recorded at negative potentials $(-60 \mathrm{mV}) . A, \mathrm{Zn}^{2+}$ concentrations correspond to free $\mathrm{Zn}^{2+}$ concentrations in solutions buffered with tricine ( $10 \mathrm{mM}$; see Fig. 2 and Materials and Methods). Data are from seven cells, with each point being the mean of three to four values. The estimated $\mathrm{IC}_{50(1)}, \mathrm{IC}_{50(2)}, a$, and $b$ are $17 \mathrm{nM}, 26 \mu \mathrm{M}, 0.75$, and 0.25 , respectively. $B, \mathrm{Zn}^{2+}$ concentrations correspond to added $\mathrm{Zn}{ }^{2+}$ concentrations corrected for an assumed $10 \mathrm{nM}$ contaminating $\mathrm{Zn}^{2+}$. TPEN $(1 \mu \mathrm{M} ; n=13)$ or DTPA $(2 \mu \mathrm{M} ; n=4)$ were used for reference (" 0 ” $\mathrm{Zn}{ }^{2+}$ concentration). Data are from 17 cells, each point being the value obtained from 1 cell (30 and $300 \mathrm{nM}$ added $\mathrm{Zn}^{2+}$ ) or the mean value obtained from 2 cells $(5$ and $10 \mathrm{nM}$ and $3 \mu \mathrm{M}), 3$ cells $(30$ and $300 \mu \mathrm{M}), 4$ cells $(1$ and $100 \mathrm{nM}), 9$ cells $(10$ and $100 \mu \mathrm{M})$, or 17 cells $(1 \mu \mathrm{M})$. The estimated IC $\mathrm{C}_{50(1)}$, $\mathrm{IC}_{50(2)}, a$, and $b$ are $6 \mathrm{nM}, 32 \mu \mathrm{M}, 0.78$, and 0.22 , respectively. $C$, A single-binding-site isotherm is sufficient to describe the $\mathrm{Zn}^{2+}$ inhibition of NR1a-NR2B responses recorded at negative potentials $(-60 \mathrm{mV}) . \mathrm{Zn}^{2+}$ concentrations correspond to added $\mathrm{Zn}^{2+}$ concentrations with no correction for $\mathrm{Zn}^{2+}$ contamination. TPEN $(1 \mu \mathrm{M})$ was used for the " 0 " $\mathrm{Zn}{ }^{2+}$ solution. Data are from five cells, with each point being the mean of three to five values. The value of $a$ was fixed to 1 . The estimated $\mathrm{IC}_{50}$ and $n$ are $490 \mathrm{~nm}$ and 0.78 , respectively. $D$, At positive potentials the low-affinity $\mathrm{Zn}^{2+}$ inhibition of NR1a-NR2A responses is absent. $\mathrm{Zn}^{2+}$ concentrations were corrected by assuming $10 \mathrm{~nm}$ contaminating $\mathrm{Zn}^{2+}$. TPEN (1 $\mu$ M; $\left.n=13\right)$ or DTPA (2 $\mu \mathrm{M} ; n=4)$ were used for the " 0 " $\mathrm{Zn}^{2+}$ concentration. Data are from 17 cells, each point being the value for 1 cell $\left(5,30\right.$, and $300 \mathrm{nM}$ added $\left.\mathrm{Zn}{ }^{2+}\right)$ or the mean value for 2 cells $(10 \mathrm{nM}$ and 3 and $30 \mu \mathrm{M}), 3$ cells $(1 \mathrm{nM}$ and $300 \mu \mathrm{M}), 4$ cells $(100 \mathrm{nM}), 8$ cells $(10$ and $100 \mu \mathrm{M})$, or 17 cells $(1 \mu \mathrm{M})$. The value of $n$ was fixed to 1 . The estimated values of the $\mathrm{IC}_{50}$ and of $a$ are $5 \mathrm{nM}$ and 0.79 , respectively.

Indeed, as illustrated in Figure 2B, NR1a-NR2B responses recorded in oocytes were sensitive to $\mathrm{Zn}^{2+}$ concentrations (nonbuffered solutions) in the hundreds of nanomolars range and could be inhibited fully, at all potentials, by $\mathrm{Zn}^{2+}$ concentrations of a few tens of micromolars. Interestingly, in this latter concentration range careful observation of the (already highly inhibited) currents revealed a voltage-dependent component of the inhibition (Fig. 2D). This voltage-dependent inhibition was similar to that observed for NR1a-NR2A receptors (see Fig. 5A). Figure $3 C$ shows the dose-response curve obtained at $-60 \mathrm{mV}$ from five cells recorded in the same conditions as those used in Figure $2 B$. In contrast to the case of NR1a-NR2A receptors, fitting the data obtained on NR1a-NR2B receptors did not require correction of the $\mathrm{Zn}^{2+}$ concentration for contaminating $\mathrm{Zn}^{2+}$. At $-60 \mathrm{mV}$ the inhibition of NR1a-NR2B responses by $\mathrm{Zn}^{2+}$ could be described by a single-binding-site isotherm with an $\mathrm{IC}_{50}$ of $490 \mathrm{~nm}$ ranging 
from 0 to $100 \%$ of the maximal response. Moreover, the $\mathrm{IC}_{50}$ for $\mathrm{Zn}^{2+}$ inhibition is in large part voltage-independent. The relative current amplitudes measured at $+50 \mathrm{mV}$ for NR1a-NR2B receptors were fit correctly by a single isotherm with an $\mathrm{IC}_{50}$ of 530 nM ( $n=3$; data not shown). Thus, $\mathrm{Zn}^{2+}$ behaves as a full antagonist of NR1a-NR2B receptors acting mainly via a voltageindependent mechanism.

In summary, $\mathrm{Zn}^{2+}$ exerts a dual block on both NMDA NR1aNR2A and NR1a-NR2B receptors: the first, which is voltageindependent, is seen at lower $\mathrm{Zn}^{2+}$ concentrations than the second, which is voltage-dependent. Quantitatively, there are two major differences between the voltage-independent $\mathrm{Zn}^{2+}$ inhibition of NR1a-NR2A and NR1a-NR2B receptors. The $\mathrm{IC}_{50}$ of the voltage-independent inhibition is, under the recording conditions used here, 50-fold lower for NR1a-NR2A receptors than for NR1a-NR2B receptors. Moreover, the voltage-independent inhibition can block only $80 \%$ of NR1a-NR2A responses, whereas it can block entirely NR1a-NR2B responses.

\section{Slow dissociation of $\mathrm{Zn}^{2+}$ from NR1a-NR2A receptors}

Further evidence for a high-affinity voltage-independent $\mathrm{Zn}^{2+}$ inhibition of NR1a-NR2A responses was obtained by analyzing the relaxations produced by $\mathrm{Zn}^{2+}$ concentration jumps applied during a NMDA response. These experiments were performed on transfected HEK cells lifted from the bottom of the dish to allow rapid solution exchange. Tricine $(10 \mathrm{~mm})$ was present both in the " 0 " $\mathrm{Zn}^{2+}$ solution and in the test solution. The presence of free tricine at a nearly constant level throughout the experiment minimized the chance of repetitive binding of $\mathrm{Zn}^{2+}$ in a putative region of restricted diffusion that artifactually could slow the relaxation kinetics. The free $\mathrm{Zn}^{2+}$ concentration was a few tens of nanomolars, a range in which $\mathrm{Zn}^{2+}$ produces only the highaffinity voltage-independent inhibition (see Fig. $3 A$ ). Representative traces of concentration jump experiments are shown in Figure 4. The current relaxations observed at the onset and at the offset of the $\mathrm{Zn}^{2+}$ application were well fit by single exponentials. In the example illustrated, the on and off time constants were 390 msec and $1.7 \mathrm{sec}$, respectively, for a free $\mathrm{Zn}^{2+}$ concentration of $20 \mathrm{~nm}$ (Fig. 4A). The corresponding values were $116 \mathrm{msec}$ and 1.9 sec with $100 \mathrm{~nm}$ free $\mathrm{Zn}^{2+}$ (Fig. 4B). Similar values were obtained in a series of four experiments performed at $-50 \mathrm{mV}$ with a free $\mathrm{Zn}^{2+}$ concentration of $20 \mathrm{nM}: \tau_{\text {on }}=370 \pm 80 \mathrm{msec} ; \tau_{\text {off }}=$ $1.7 \pm 0.2 \mathrm{sec}$.

Assuming that there is only one high-affinity voltageindependent $\mathrm{Zn}^{2+}$ binding site and that $\mathrm{Zn}^{2+}$ interaction with the receptor follows a simple bimolecular reaction (as suggested by the Hill coefficient, close to 1 ; see Fig. 3), the onset time constant, $\tau_{\text {on }}$, should depend on the $\mathrm{Zn}^{2+}$ concentration $\left[\tau_{\text {on }}=\right.$ $1 /\left(\left[\mathrm{Zn}^{2+}\right] k_{\text {on }}+k_{\text {off }}\right)$, in which $k_{\text {on }}$ is the $\mathrm{Zn}^{2+}$ association rate constant and $k_{\text {off }}$ the $\mathrm{Zn}^{2+}$ dissociation rate constant]. The offset time constant, $\tau_{\text {off }}$, should be independent of the $\mathrm{Zn}^{2+}$ concentration $\left(\tau_{\text {off }}=1 / k_{\text {off }}\right)$. These simple predictions were, indeed, fulfilled. $k_{\text {on }}$ was found to be close from $10^{8} \mathrm{M}^{-1} \cdot \mathrm{sec}^{-1} \cdot k_{\text {off }}$ was estimated to be $0.6 \mathrm{sec}^{-1}$. The $K_{\mathrm{D}}$ derived from these values $\left(K_{\mathrm{D}}\right.$ $=k_{\text {off }} / k_{\text {on }}$ ) was $6 \mathrm{~nm}$, a value in very good agreement with the values estimated independently from dose-response curves. It is worth noting that such a result does not depend on the expression system, because concentration jumps were performed on HEK cells, whereas dose-response curves were obtained with Xenopus oocytes.

We also performed concentration jump experiments on NR1aNR2B receptors. Two series of experiments were performed, one
$1 \mathrm{a} / 2 \mathrm{~A}$

A

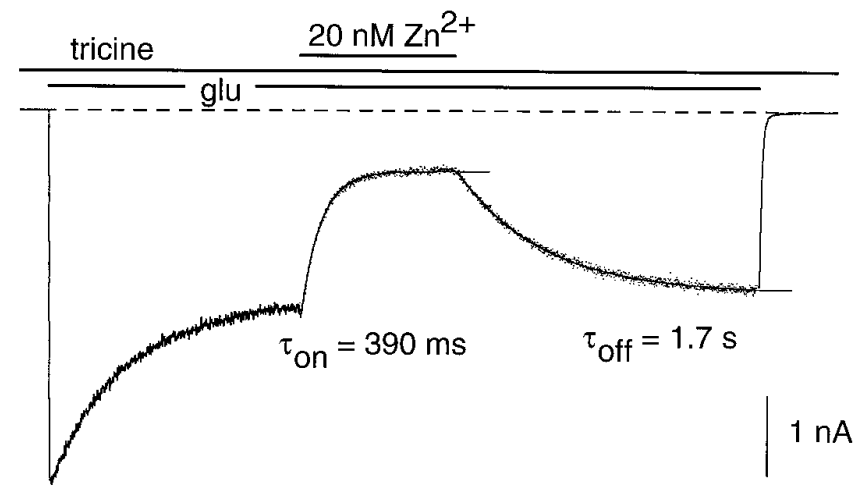

B

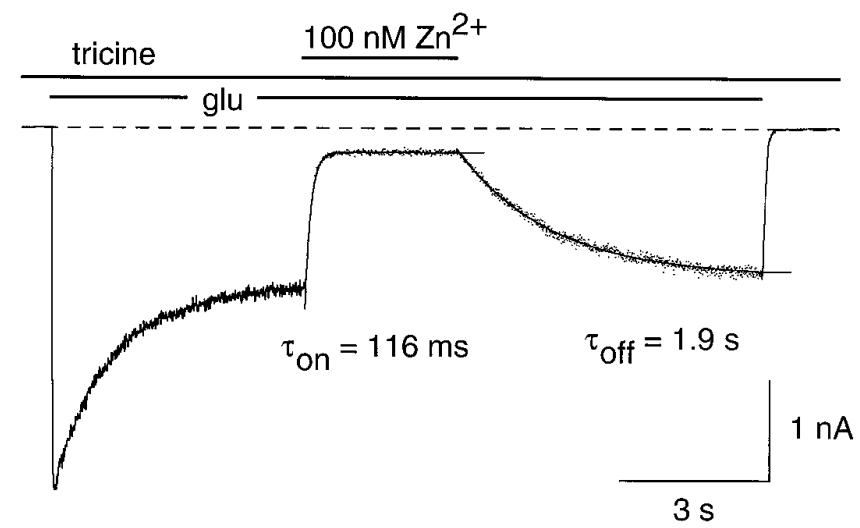

Figure 4. Slow dissociation of $\mathrm{Zn}^{2+}$ from NR1a-NR2A receptors. Current relaxations that follow a $\mathrm{Zn}^{2+}$ concentration jump were analyzed in HEK 293 cells expressing NR1a-NR2A receptors. Each trace represents an individual response to a $14.5 \mathrm{sec}$ pulse of glutamate $(100 \mu \mathrm{M})$ on a background of glycine $(100 \mu \mathrm{M})$. Tricine $(10 \mathrm{mM})$ was present throughout the experiment. $\mathrm{Zn}^{2+}$ was applied for $3 \mathrm{sec}$ during the pulse of glutamate once the response had reached a steady level. The $\mathrm{Zn}^{2+}$ concentrations as indicated in the figure correspond to the calculated free $\mathrm{Zn}^{2+}$ concentration in the tricine-buffered solutions (see Materials and Methods). The onset and offset of the inhibition by $\mathrm{Zn}^{2+}$ were fit by single exponentials (superimposed on the current traces) with time constants $\tau_{\text {on }}$ and $\tau_{\text {off }}$, as indicated in the figure. Data were filtered at $100 \mathrm{~Hz}$ and sampled at $140 \mathrm{~Hz}$. The holding potential was $-50 \mathrm{mV}$.

under conditions similar to those used for NR1a-NR2A receptors (1 $\mathrm{mm}$ extracellular $\mathrm{Ca}^{2+}$ ions) and the other in which extracellular $\mathrm{Ca}^{2+}$ ions were replaced by $0.3 \mathrm{~mm} \mathrm{Ba}^{2+}$ to mimic the conditions used for obtaining $\mathrm{Zn}^{2+}$ dose-response curves in oocytes. Because of the low affinity of the NR1a-NR2B receptors for $\mathrm{Zn}^{2+}$ (see Fig. 3C), these experiments required relatively high $\mathrm{Zn}^{2+}$ concentrations $(1-5 \mu \mathrm{M})$. As a consequence, the $\mathrm{Zn}^{2+}$-induced on-relaxations were very fast $(\tau \leq 50 \mathrm{msec})$, and the evaluation of their time constant was made uncertain by the relatively slow speed of our whole-cell perfusion system (time constant, $\sim 20 \mathrm{msec}$ ). This limitation did not apply to the evaluation of the off-relaxations. In the two sets of experiments the off-relaxations after $\mathrm{Zn}^{2+}$ withdrawal were very similar $\left[\tau_{\text {off }}=\right.$ $63 \pm 17 \mathrm{msec}(n=6)$ with $1 \mathrm{mM} \mathrm{Ca}^{2+}$ and $\tau_{\text {off }}=70 \pm 14 \mathrm{msec}$ 
$(n=3)$ with $0.3 \mathrm{mM} \mathrm{Ba}^{2+}$ ] and much faster than those observed with NR1a-NR2A receptors (see above). The rate of $\mathrm{Zn}^{2+}$ dissociation calculated from these relaxations was on the order of $15 \mathrm{sec}^{-1}$, i.e., $\sim 25$-fold larger than that calculated for NR1a$\mathrm{NR} 2 \mathrm{~A}$ receptors.

Using this dissociation rate value and the amount of steadystate $\mathrm{Zn}^{2+}$ inhibition measured at the end of the $\mathrm{Zn}^{2+}$ application $\left[53 \pm 7 \%(n=4)\right.$ with $1 \mathrm{mM} \mathrm{Ca}^{2+}$ and $5 \mu \mathrm{M} \mathrm{Zn}^{2+} ; 49 \pm 2 \%$ with $0.3 \mathrm{mM} \mathrm{Ba}^{2+}$ and $1 \mu \mathrm{M} \mathrm{Zn^{2+ }}$ ], we calculated $\mathrm{Zn}^{2+}$ association rates of $3.2 \cdot 10^{6} \mathrm{M}^{-1} \cdot \mathrm{sec}^{-1}$ and $1.4 \cdot 10^{7} \mathrm{M}^{-1} \cdot \mathrm{sec}^{-1}$, respectively. The sensitivity of these rates to the external divalent ions $\mathrm{Ca}^{2+}$ and $\mathrm{Ba}^{2+}$ suggests that these ions compete with $\mathrm{Zn}^{2+}$ for occupancy of the voltage-independent inhibition site in NR1a-NR2B. This would explain why the steady-state inhibition observed with these receptors in the presence of $1 \mathrm{mM} \mathrm{Ca}^{2+}$ and $5 \mu \mathrm{M} \mathrm{Zn^{2+ }}$ was much lower than that predicted by the apparent $K_{\mathrm{D}}$ of $0.5 \mu \mathrm{M}$ measured in oocytes. Replacing external $\mathrm{Ca}^{2+}$ by $\mathrm{Ba}^{2+}$ had no significant effect on $\mathrm{Zn}^{2+}$ inhibition of NR1a$\mathrm{NR} 2 \mathrm{~A}$ receptors (data not shown). The difference in $\mathrm{Zn}^{2+}$ onrates between $\mathrm{NR} 1 \mathrm{a}-\mathrm{NR} 2 \mathrm{~A}$ and $\mathrm{NR} 1 \mathrm{a}-\mathrm{NR} 2 \mathrm{~B}$ receptors thus could, at least partly, result from a lowering of the NR1a-NR2B on-rate by the competition among $\mathrm{Zn}^{2+}, \mathrm{Ca}^{2+}$, and $\mathrm{Ba}^{2+}$.

Overall, the results of the concentration jump experiments indicate that the difference of $\mathrm{Zn}^{2+}$ affinity between NR1a$\mathrm{NR} 2 \mathrm{~A}$ and NR1a-NR2B receptors is attributable mainly to a difference in the dissociation rate of $\mathrm{Zn}^{2+}$.

\section{The low-affinity voltage-dependent $\mathrm{Zn}^{2+}$ block}

As shown in Figures 2 and 3, at negative potentials and at high enough $\mathrm{Zn}^{2+}$ concentrations (1-100 $\left.\mu \mathrm{M}\right)$ a voltage-dependent blocking action of $\mathrm{Zn}^{2+}$ is superimposed on the voltageindependent one. This voltage-dependent inhibition is seen with both NR1a-NR2A and NR1a-NR2B responses, but in the second case it is masked by the fact that it overlaps with the voltage-independent block (see Fig. $2 C, D$ ). Consequently, the voltage-dependent $\mathrm{Zn}^{2+}$ inhibition was characterized more easily on NR1a-NR2A receptors.

Figure $5 A$ shows representative current-voltage relations of NR1a-NR2A currents recorded in Xenopus oocytes at different $\mathrm{Zn}^{2+}$ concentrations in the micromolar range $(1,10,30,100$, and $300 \mu \mathrm{M}$ from -100 to $+50 \mathrm{mV}$ ). The traces are shown on an expanded current scale to restrict the display to the component of the maximal response that remains after addition of $1 \mu \mathrm{M} \mathrm{Zn}^{2+}$ has saturated the site responsible for the high-affinity voltageindependent inhibition. Increasing the concentration of $\mathrm{Zn}^{2+}$ above $1 \mu \mathrm{M}$ produced little change in the outward currents but markedly reduced the inward currents. The fraction of the channels that were not blocked by the voltage-dependent process (the unblocked fraction) was evaluated as the ratio (normalized to 1 at $+50 \mathrm{mV}$ ) of the glutamate-induced current measured during a voltage ramp in the presence of $\mathrm{Zn}^{2+}$ over the current in " 0 " $\mathrm{Zn}^{2+}$ solution. Figure $5 B$ shows that the block increased as the potential was made more negative. The voltage dependence of the $\mathrm{Zn}^{2+}$ block differs from that seen in the same system with $\mathrm{Mg}^{2+}$ (see Kuner and Schoepfer, 1996): in the presence of $\mathrm{Zn}^{2+}$, below $-60 \mathrm{mV}$ the inward current becomes nearly independent of the potential, in contrast to the case of $\mathrm{Mg}^{2+}$, in which at very negative potentials the current tends to zero, leading to the "bell-shaped" current-voltage relations described by Nowak et al. (1984) and by Mayer et al. (1984). Even at the highest $\mathrm{Zn}^{2+}$ concentration tested $(300 \mu \mathrm{M})$ and at the most negative potentials applied $(-100 \mathrm{mV})$, the response is not blocked fully. The ab- sence of a parallel shift between the different unblocked fraction curves obtained with increasing $\mathrm{Zn}^{2+}$ concentrations further suggests that the voltage-dependent $\mathrm{Zn}^{2+}$ inhibition is different from the $\mathrm{Mg}^{2+}$ block of NMDA responses, possibly because $\mathrm{Zn}^{2+}$ ions can permeate (escape) more readily through the channel (see Discussion).

The affinity for $\mathrm{Zn}^{2+}$ of the site accounting for the voltagedependent block of the NR1a-NR2A receptor was determined at different membrane potentials, using values obtained from normalized unblocked fraction plots such as the one shown in Figure $5 B$ (see Materials and Methods). The block by $\mathrm{Zn}^{2+}$ was well fit by a single-binding-site isotherm over the range from -100 to 0 $\mathrm{mV}$ (Fig. $5 C$ ), assuming that the slight voltage dependence observed at $1 \mu \mathrm{M} \mathrm{Zn^{2+ }}$ is attributable to an unrelated effect (e.g., binding to surface charges or to a superficial divalent binding site in the external vestibule of the pore; see Ascher and Nowak, 1988; Premkumar and Auerbach, 1996). The calculated apparent $K_{\mathrm{D}}$ values were $22 \mu \mathrm{M}$ at $-100 \mathrm{mV}, 31 \mu \mathrm{M}$ at $-80 \mathrm{mV}, 41 \mu \mathrm{M}$ at -60 $\mathrm{mV}, 100 \mu \mathrm{M}$ at $-40 \mathrm{mV}, 346 \mu \mathrm{M}$ at $-20 \mathrm{mV}$, and $1162 \mu \mathrm{M}$ at $0 \mathrm{mV}$ (Fig. $5 D$ ). The last value (at $0 \mathrm{mV}$ ) is five orders of magnitude higher than that of the voltage-independent antagonism $(\sim 10 \mathrm{nM}$; see Fig. 3). The fact that the apparent $K_{\mathrm{D}}$ is not a simple exponential function of the membrane potential is expected from a model in which the blocking ion is permeant (see Discussion).

\section{A pore mutation in NR2A selectively suppresses the voltage-dependent $\mathbf{Z n}^{2+}$ inhibition}

Our data are in agreement with the idea that $\mathrm{Zn}^{2+}$ acts at two different sites on NR1a-NR2A receptors: one extracellular, outside the membrane field and accounting for the high-affinity voltage-independent inhibition, and the other inside the channel, accounting for the voltage-dependent block (Christine and Choi, 1990). To try to dissociate the two sites, we used mutated NMDA receptors and took advantage of the fact that the voltagedependent $\mathrm{Zn}^{2+}$ inhibition presents some similarities with the $\mathrm{Mg}^{2+}$ block of NMDA channels and that molecular determinants involved in $\mathrm{Mg}^{2+}$ block have been identified. The strongest effects on $\mathrm{Mg}^{2+}$ block were obtained by mutating the residue occupying the $\mathrm{Q} / \mathrm{R} / \mathrm{N}$ site of the $\mathrm{M} 2$ region, the putative channelforming segment of the protein. In particular, Burnashev et al. (1992), Sakurada et al. (1993), and Kawajiri and Dingledine (1993) showed that the substitution of asparagine N598 of the NR1 subunit by an arginine results in a total suppression of the external $\mathrm{Mg}^{2+}$ block. We found that a similar effect could be obtained by replacing asparagine N595 of the NR2A subunit by a lysine [NR2A(N595K)] (unpublished results). Consequently, we expressed NR1a-NR2A(N595K) receptors in Xenopus oocytes and compared their sensitivity to $\mathrm{Zn}^{2+}$ and to heavy metal chelators with that of wild-type NR1a-NR2A receptors.

As shown in Figure $6 A$, at $-60 \mathrm{mV}$ the strong inhibition produced by $1 \mu \mathrm{M} \mathrm{Zn}^{2+}$ was comparable for the mutant and wild-type receptors. The ratio of the current recorded in $1 \mu \mathrm{M}$ added $\mathrm{Zn}^{2+}$ over the current recorded in " 0 " $\mathrm{Zn}^{2+}$ was $0.19 \pm$ $0.02(n=5)$ for the mutant receptors and $0.22 \pm 0.04(n=17)$ for the wild-type receptors (see Fig. $3 B$ ). In contrast, the additional voltage-dependent inhibition of NR1a-NR2A responses produced by $100 \mu \mathrm{M} \mathrm{Zn}^{2+}$ was not observed with NR1aNR2A(N595K) responses $(n=7)$.

Voltage ramps applied to oocytes expressing NR1a$\mathrm{NR} 2 \mathrm{~A}(\mathrm{~N} 595 \mathrm{~K})$ receptors confirmed that the currents recorded in the presence of 1 and $100 \mu \mathrm{M} \mathrm{Zn^{2+ }}$ were identical over the whole voltage range tested (from -100 to $+50 \mathrm{mV}$ ), indicating the 
A

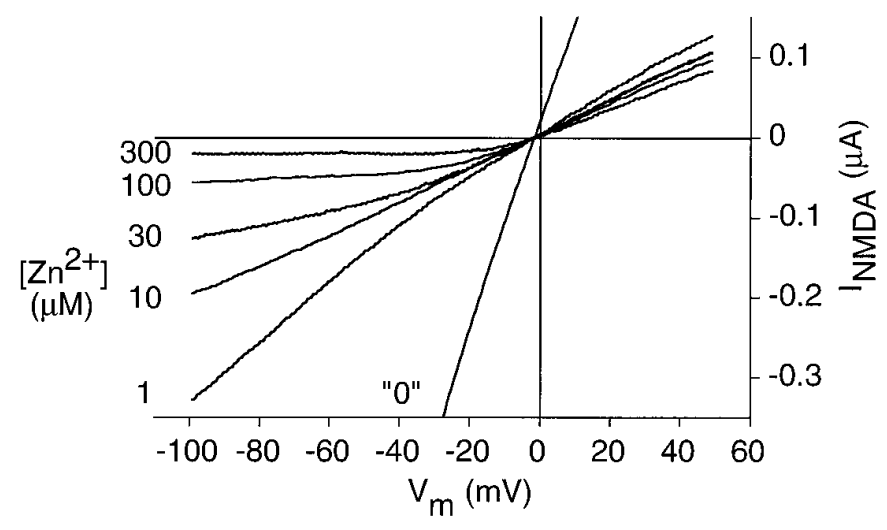

B

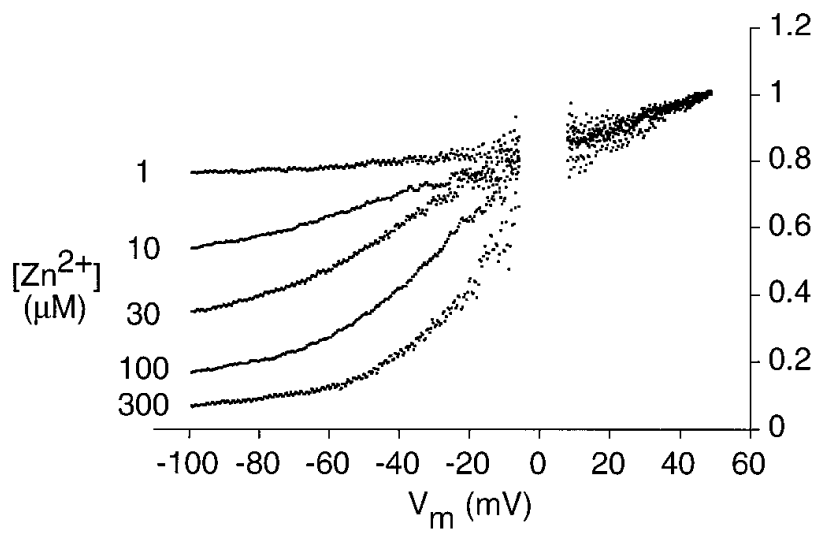

C

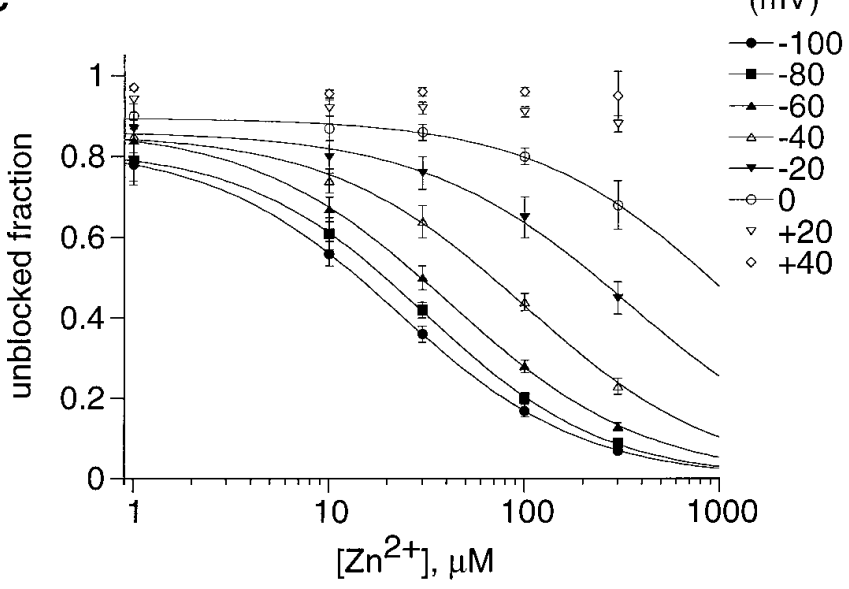

D

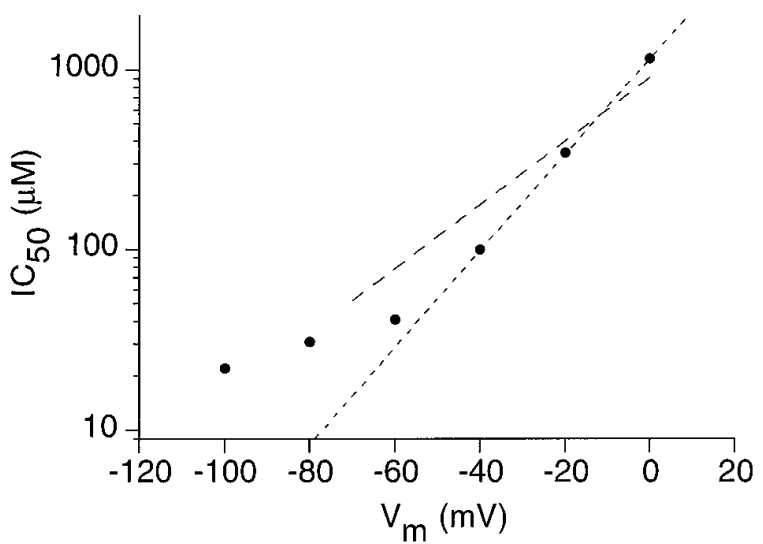

Figure 5. Low-affinity voltage-dependent $\mathrm{Zn}^{2+}$ block of NMDA NR1a-NR2A responses. $A$, Voltage ramps from -100 to $+50 \mathrm{mV}$ were applied in Xenopus oocytes expressing NR1a-NR2A receptors in the absence of $\mathrm{Zn}^{2+}$ ( " 0 " $\mathrm{Zn}^{2+}$ solution containing $2 \mu \mathrm{M}$ DTPA) or after the addition of 1, 10, 30,100 , or $300 \mu \mathrm{M}$ added $\mathrm{Zn}^{2+}$. For clarity, leak-substracted $I-V$ curves are shown on an expanded current scale, because the voltage-dependent block by $\mathrm{Zn}^{2+}$ appears in a concentration range in which $\sim 80 \%$ of the maximal response already is eliminated by the high-affinity voltage-independent $\mathrm{Zn}{ }^{2+}$ inhibition (see Figs. 2, 3). The $\mathrm{Zn}^{2+}$ block increases with increasing $\mathrm{Zn}^{2+}$ concentrations and with hyperpolarization. However, even at the highest concentration of $\mathrm{Zn}^{2+}$ tested $(300 \mu \mathrm{M})$ and at the most negative potentials, an inward current can still be recorded. $B$, Voltage dependence of the low-affinity $\mathrm{Zn}^{2+}$ inhibition. Shown is the same cell as in $A$. The unblocked fraction was calculated by dividing, at each concentration of $\mathrm{Zn}{ }^{2+}$, the NMDA current by the NMDA current recorded in " 0 " $\mathrm{Zn}^{2+}$ and by subsequently normalizing to 1 for a membrane potential of $+50 \mathrm{mV}$. Data points that take artifactual values around the reversal potential have been omitted. $C$, Concentration dependence of the voltage-dependent block by $\mathrm{Z} \mathrm{n}^{2+}$ at $-100,-80,-60,-40,-20,0,+20$, and $+40 \mathrm{mV}$. Data points were calculated from curves similar to those shown in $B$, obtained in a series of seven experiments. Each point corresponds to the mean value obtained from three to seven measurements. The data points at $0 \mathrm{mV}$ were obtained by interpolation with a polynomial fit (see Materials and Methods). The lines drawn through the data points are least-squares fits of the single binding isotherm: $y=y_{\max } \cdot\left(1-\left(1 /\left(1+\left(\mathrm{IC}_{50} /\left[\mathrm{Zn}^{2+}\right]\right)^{n}\right)\right)\right)$, in which $y$ is the relative voltage-dependent $\mathrm{Zn}^{2+}$ inhibition and $n$ is the Hill coefficient. The weight factor $y_{\max }$ was introduced to eliminate the residual voltage dependence seen at $1 \mu \mathrm{M} \mathrm{Zn}{ }^{2+}$ (see Results). The estimated $\mathrm{IC}_{50}$ and $n$ are, respectively, $22 \mu \mathrm{M}$ and 0.9 at $-100 \mathrm{mV}, 31 \mu \mathrm{M}$ and 0.9 at $-80 \mathrm{mV}, 41 \mu \mathrm{M}$ and 0.9 at $-60 \mathrm{mV}, 100 \mu \mathrm{M}$ and 0.9 at $-40 \mathrm{mV}, 346 \mu \mathrm{M}$ and 0.9 at $-20 \mathrm{mV}$, and 1162 $\mu \mathrm{M}$ and 0.8 at $0 \mathrm{mV}$. D, Voltage dependence of the low-affinity $\mathrm{Zn}^{2+}$ inhibition. The $\mathrm{IC}_{50}$ values are those estimated by the fits shown in $C$. Note that, on this semi-log plot, a linear relation does not fit the data. The slope of the relation between the $\mathrm{IC}_{50}$ and the voltage increases with depolarization and reaches a maximum between -40 and $0 \mathrm{mV}$. In this range the slope (e-fold for $\sim 16 \mathrm{mV}$, dotted line) is consistent with an apparent electrical depth of the $\mathrm{Zn}^{2+}$ binding site of 0.77 . The dashed line is drawn according to the equation used by Christine and Choi (1990) for the fit of their single-channel data obtained in the range between -70 and $-20 \mathrm{mV}$ (an $\mathrm{IC}_{50}$ at $0 \mathrm{mV}$ of $909 \mu \mathrm{M}$ and an electrical depth of 0.51 ).

disappearance of the voltage-dependent block. The voltageindependent inhibition was not affected by the mutation and, as in the wild-type receptors, affected only $\sim 80 \%$ of the maximal response at saturating $\mathrm{Zn}^{2+}$ concentrations (Fig. $6 B$, reproduced in seven cells). Moreover, we found that, like NR1a-NR2A responses, NR1a-NR2A(N595K) responses were potentiated by the addition of $1 \mu \mathrm{M}$ TPEN (current ratio TPEN/control $=2.1 \pm$ $0.1 ; n=2)$.

\section{Heavy metal chelators potentiate native NMDA responses}

The effect of TPEN was investigated on native NMDA receptors in nucleated patches excised from embryonic mouse cortical and diencephalic neurons (Sather et al., 1992). The experimental conditions were identical to those used for the HEK cells, except that glutamate was replaced by NMDA to activate specifically the NMDA type of glutamate receptors. Most neuronal NMDA 
A

$1 a / 2 A$

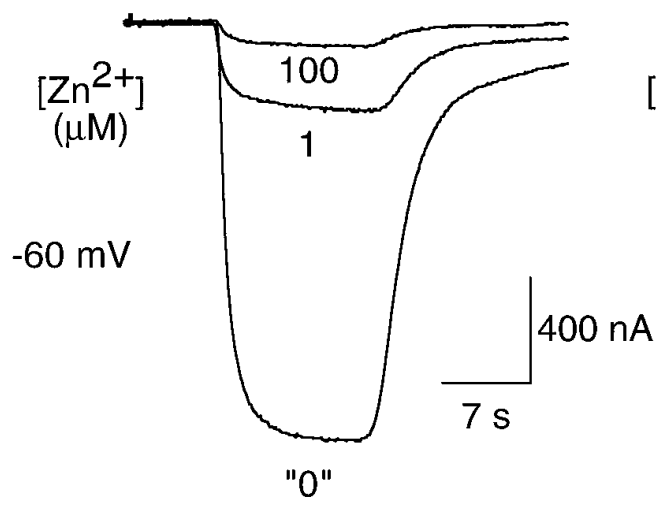

1a/2A(N595K)

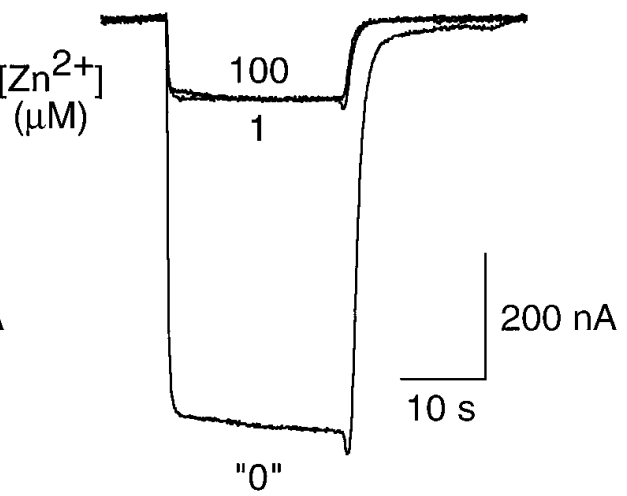

Figure 6. A pore mutation selectively eliminates the low-affinity voltagedependent $\mathrm{Zn}^{2+}$ inhibition. $A$, Comparison of the inhibitory effects of $\mathrm{Zn}^{2+}$ on NMDA responses recorded at $-60 \mathrm{mV}$ in oocytes expressing wild-type NR1aNR2A receptors or mutant NR1aNR2A(N595K) receptors. Shown are superimposed individual responses to a 20 sec pulse of glutamate and glycine (100 $\mu \mathrm{M}$ each) recorded in the presence of a $\mathrm{Zn}^{2+}$ chelator (" 0 " $\mathrm{Zn}^{2+}$ concentration; $1 \mu \mathrm{M}$ TPEN for wild-type receptors and $2 \mu \mathrm{M}$ DTPA for mutant receptors) or in the presence of 1 or $100 \mu \mathrm{M}$ added $\mathrm{Zn}^{2+}$. Both types of receptors are strongly inhibited by $1 \mu \mathrm{M} \mathrm{Zn}^{2+}$, but the presence

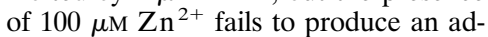
ditional inhibition on the mutant receptors. $B$, Leak-substracted $I-V$ curves from Xenopus oocytes expressing the mutant NR1a-NR2A(N595K) receptors in the absence ("0" $\mathrm{Zn}^{2+} ; 2 \mu \mathrm{M}$ DTPA) or in the presence of added $\mathrm{Zn}^{2+}(1$ and 100 $\mu \mathrm{M})$. The traces obtained in 1 and $100 \mu \mathrm{M}$ $\mathrm{Zn}^{2+}$ are superimposed almost perfectly over the whole voltage range, indicating that the voltage-dependent inhibition by $\mathrm{Zn}^{2+}$ has been suppressed by the mutation.

responses were potentiated by the presence of $1 \mu \mathrm{M}$ TPEN (11 cells of 12), but the potentiating factor was highly variable from one neuron to the other, ranging from 1.1-fold to a maximum of 1.6-fold (Fig. $7 A$; mean potentiation $1.25 \pm 0.17 ; n=12$ ). Figure $7 B$ illustrates two examples representative of the range of the effect of TPEN on neuronal NMDA currents: one with a clear potentiation (top panel, peak current ratio TPEN/control $=1.4$ ) and the other with virtually no potentiation (bottom panel, peak current ratio $\mathrm{TPEN} /$ control $=1.0$ ).

The potentiations observed in neuronal receptors were never larger than twofold, whereas a factor of three was common with NR1a-NR2A receptors. This could indicate that, in our cultures, there are none or very few neurons endowed exclusively with NR1a-NR2A receptors, consistent with some previous findings (see Discussion and Paoletti et al., 1995). On the other hand, the results show that the large majority of neurons does express NMDA receptors that are potentiated by the addition of micro- molar concentrations of TPEN and therefore are inhibited substantially by a contaminant heavy metal present at a submicromolar concentration. This suggests that most of the tested neurons contained a fraction of NMDA receptors highly sensitive to $\mathrm{Zn}^{2+}$.

The large variability of the magnitude of the potentiation by TPEN of native receptors probably reflects the subunit composition heterogeneity known to occur in primary cultures of neurons (Williams et al., 1993; Audinat et al., 1994; Paoletti et al., 1995). This suggestion was reinforced by expanding the study of the effects of the addition of TPEN and by determining the $\mathrm{Zn}^{2+}$ binding affinities of recombinant NMDA receptors (expressed in Xenopus oocytes) other than NR1a-NR2A and NR1a-NR2B. The absence of an effect of TPEN on NR1a-NR2B receptors was found also for NR1b-NR2B receptors (current ratio TPEN/ control $=0.98 \pm 0.02 ; n=4)$. The potentiating effect of TPEN seen on NR1a-NR2A receptors also was seen with NR1b- 
A

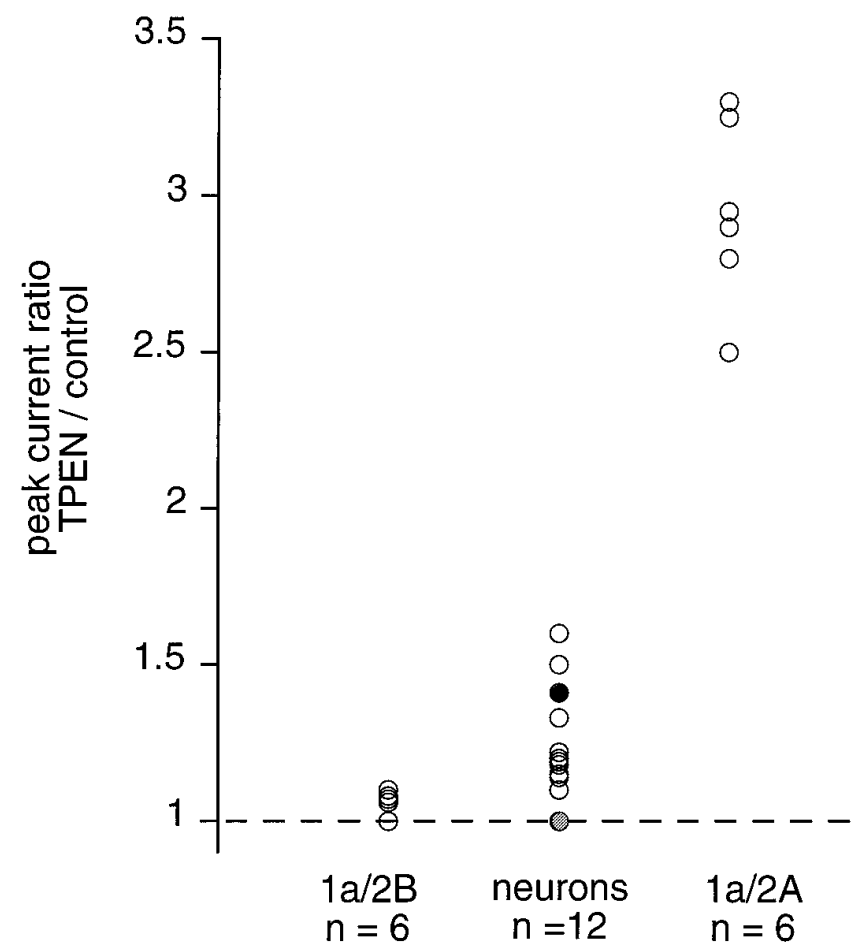

B

neurons
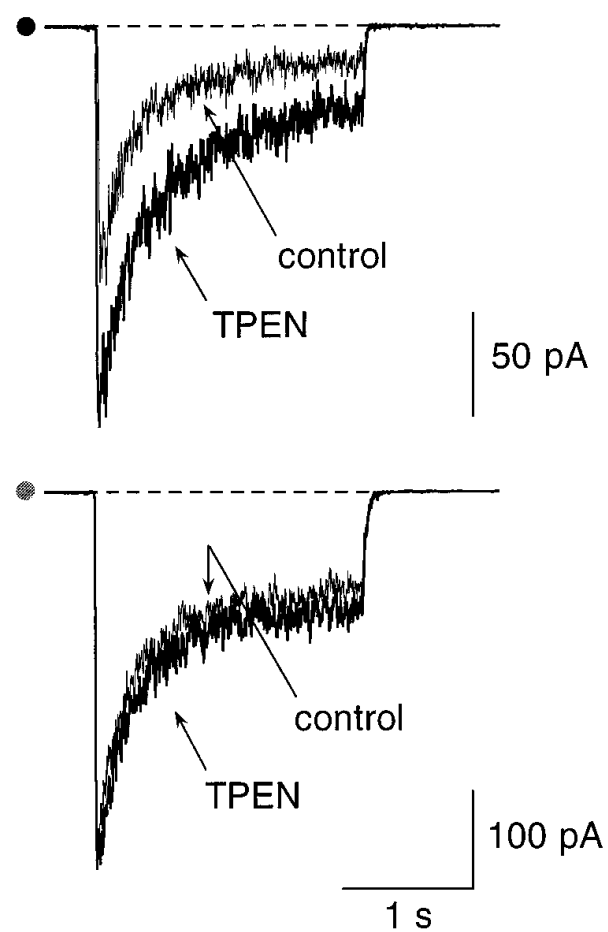

Figure 7. Most native NMDA receptors are potentiated by TPEN. $A$, Comparison of the effects of TPEN (1 $\mu \mathrm{M})$ on the peak amplitude of NMDA currents recorded in neurons and in HEK 293 cells expressing either NR1a-NR2A or NR1a-NR2B receptor subtypes. Native NMDA responses were elicited by a $2 \mathrm{sec}$ pulse of NMDA $(200 \mu \mathrm{M})$ on a background of glycine $(10 \mu \mathrm{M})$. Recombinant NMDA responses were recorded with protocols identical to those shown in Figure 1. The holding potential was $-50 \mathrm{mV}$. Each circle corresponds to the peak ratio (TPEN/control) obtained from one experiment. The filled and hatched circles correspond to the two separate experiments, which are illustrated in $B$. The potentiation of native NMDA responses by TPEN was highly variable, with peak ratios ranging from 1.0 (no potentiation) to a maximum of 1.6 . The mean value was $1.25 \pm 0.17(n=12)$. The mean peak ratios for NR1a-NR2A and NR1a-NR2B receptors were $2.9 \pm 0.3(n=6)$ and $1.07 \pm 0.04(n=6)$, respectively. $B$, Variability of the effect of TPEN on neuronal NMDA responses. Shown are superimposed traces recorded in the control solution and in the presence of $1 \mu \mathrm{M}$ TPEN. Each trace is the average of three individual responses. The top panel shows an example with a marked potentiation by TPEN (the peak ratio TPEN/control of 1.41 corresponds to the filled circle in $A$ ), whereas the bottom panel shows an example in which TPEN was ineffective (the peak ratio of 1.0 corresponds to the hatched circle in $A$ ).

Table 2. Subunit-specific voltage-independent $\mathrm{Zn}^{2+}$ inhibition

\begin{tabular}{llllll} 
& $1 \mathrm{a} / 2 \mathrm{~A}$ & $1 \mathrm{~b} / 2 \mathrm{~A}$ & $1 \mathrm{a} / 2 \mathrm{~B}$ & $1 \mathrm{~b} / 2 \mathrm{~B}$ & $1 \mathrm{a} / 2 \mathrm{C}$ \\
\hline $\mathrm{IC}_{50}$ (nM) & $\sim 10$ & 70 & 490 & 2500 & 14,000 \\
& (see Fig. 3) & $(n=4)$ & (see Fig. 3) & $(n=5)$ & $(n=4)$
\end{tabular}

Recombinant NMDA receptors were expressed in Xenopus oocytes. The $\mathrm{IC}_{50}$ values were determined as described in Figure $3 B$ for NR1b-NR2A receptors and Figure $3 C$ for NR1b-N2B and NR1a-NR2C receptors. As for NR1a-NR2A receptors, the voltage-independent $\mathrm{Zn}^{2+}$ inhibition of NR1b-NR2A receptors is partial, saturating at $\sim 70 \%$ of the maximal current. In contrast, as for NR1a-NR2B receptors, NR1b-NR2B receptors and NR1a-NR2C receptors are fully inhibited by $\mathrm{Zn}^{2+}$, mainly via a voltage-independent mechanism. The external $\mathrm{Ba}^{2+}$ concentration was $0.3 \mathrm{~mm}$, and the external $\mathrm{pH}$ was 7.3 .

NR2A receptors, but it was smaller (current ratio TPEN/control $=1.21 \pm 0.02 ; n=3)$. As shown in Table 2 , the voltageindependent $\mathrm{Zn}^{2+}$ antagonism has a unique pharmacological profile on each recombinant receptor tested. The comparison of these profiles shows that the voltage-independent $\mathrm{Zn}^{2+}$ inhibition extends over a range of three orders of magnitude (NR1a$\mathrm{NR} 2 \mathrm{~A}$ receptors being the most sensitive and NR1a-NR2C receptors being the least sensitive) and depends on the nature of both NR2 and NR1 subunits. NR1b subunits contain exon 5, a 21-amino-acid N-terminal exon that is positively charged and known to affect the interaction of NMDA receptors with positively charged molecules and ions (Hollmann et al., 1993; Wil- liams, 1994; Williams et al., 1994; Zhang et al., 1994; Zheng et al., 1994; Paoletti et al., 1995). It is interesting to note that it also appears to modify the interaction of recombinant heteromeric NMDA receptors with $\mathrm{Zn}^{2+}$.

\section{$\mathrm{Zn}^{2+}$ chelation is probably responsible for the NR2A- specific fast potentiation of NMDA responses by reducing agents}

Experiments on recombinant NMDA receptors expressed in HEK cells have shown that sulfhydryl reducing agents such as dithiothreitol (DTT) or reduced glutathione potentiate recombinant NMDA channel activity via a dual mechanism. All of the 
A
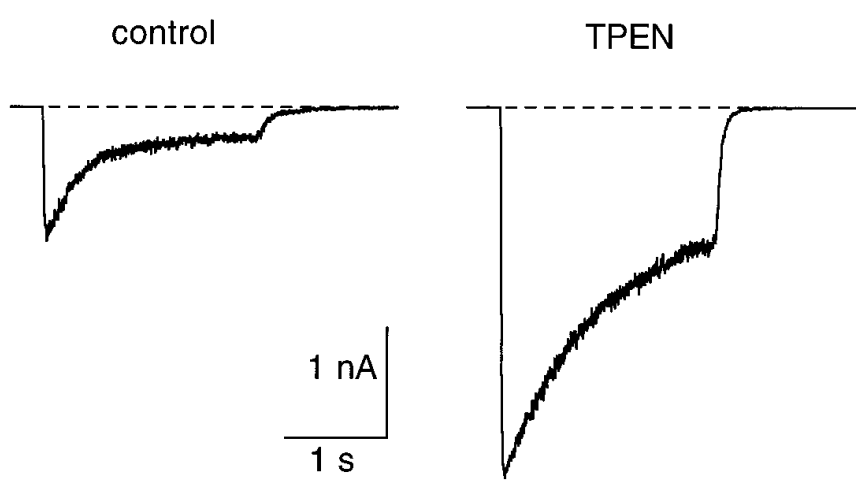

TPEN

DTE

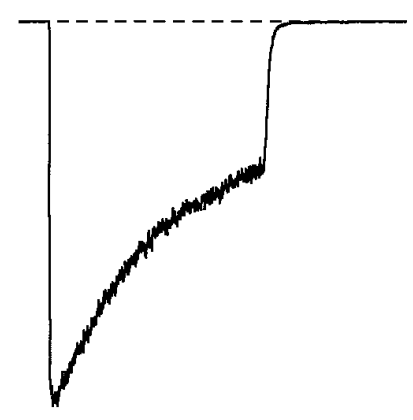

TPEN + DTE

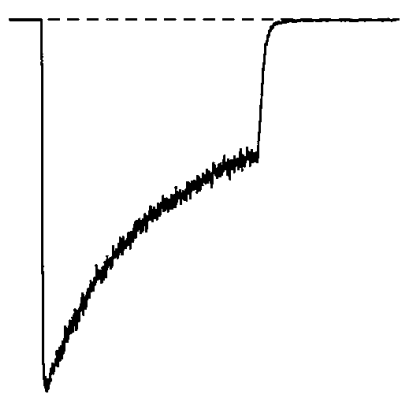

B

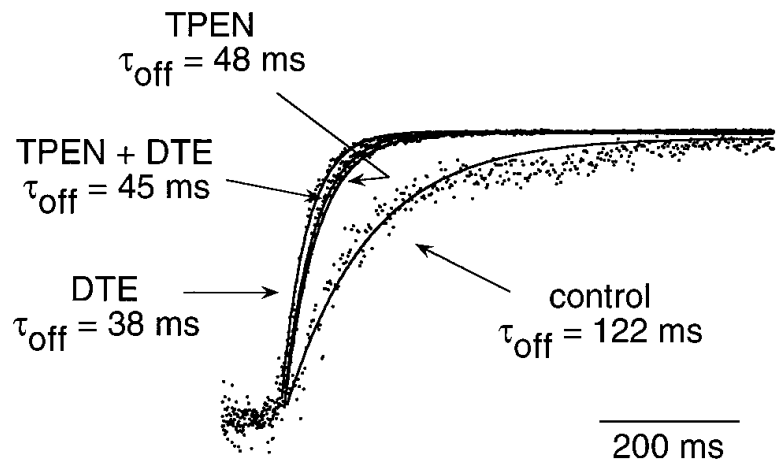

Figure 8. The NR2A subunit-specific potentiation produced by reducing agents is probably the consequence of $\mathrm{Zn}^{2+}$ chelation. Shown are glutamate-evoked currents recorded in an HEK 293 cell expressing NR1a-NR2A receptors. The cell was exposed either to a control solution or to TPEN $(1 \mu \mathrm{M})$ and DTE $(3 \mathrm{mM})$ applied separately or simultaneously. The holding potential was $-50 \mathrm{mV}$. A, Each trace is an individual response to a 2 sec pulse of glutamate $(100 \mu \mathrm{M})$ applied on a background of glycine $(100 \mu \mathrm{M})$. The potentiations produced by DTE and TPEN are not additive. B, Glutamate off-relaxations are shown on an expanded time scale and after normalization to the steady-state response amplitude. The decay of the current was fit by a single exponential function (solid lines superimposed on the current traces), with a time constant $\tau_{\text {off }}$ indicated in the figure. TPEN and DTE applied separately or simultaneously induce similar accelerations of the off response.

receptors tested (heteromers composed of NR1 subunits and of one type of the NR2 subunit family) show a slowly developing potentiation (time scale of minutes) that does not reverse after washout of the reducing agent (Köhr et al., 1994). NR1-NR2A receptors show an additional marked potentiation ( $\geq$ threefold) with a very rapid onset (maximal from the first pulse in DTT; see Köhr et al., 1994). This fast potentiation is reversed by the removal of the reducing agent and is associated with a slowing of desensitization and an acceleration of deactivation of glutamateactivated currents (Köhr et al., 1994). Both types of potentiation have been assumed to involve sulfhydryl-containing redox sites (Köhr et al., 1994). However, the striking similarities (in magnitude, in kinetics, in subunit specificity) between the NR2A subunit-specific potentiation by DTT and the NR2A subunitspecific potentiation by heavy metal chelators could be accounted for by the strong $\mathrm{Zn}^{2+}$ binding properties of DTT (absolute $K_{\mathrm{D}}$ of $10^{-10.3} \mathrm{M}$ at $\mathrm{pH}$ 9.2; Cornell and Crivaro, 1972), suggesting that the subunit-specific action of DTT is attributable to chelation of a contaminant heavy metal.

Experimental evidence for this hypothesis was obtained by testing the additivity of the potentiations produced by TPEN and DTE, the erythroisomer of DTT. In HEK cells expressing
NR1a-NR2A receptors, glutamate-activated currents were recorded in control conditions, in the presence of TPEN $(1 \mu \mathrm{M})$ or DTE ( $3 \mathrm{~mm})$, and in the presence of both TPEN and DTE. The concentration of DTE was similar to the concentration of DTT used by Köhr et al. (1994). As shown in Figure $8 A$, the potentiation produced by TPEN, by DTE, and by DTE plus TPEN were similar (current ratios: TPEN/control $=2.8 \pm 0.01, n=2$; $\mathrm{DTE} /$ control $=2.9 \pm 0.1, n=2 ; \mathrm{TPEN}+\mathrm{DTE} / \mathrm{control}=2.9 \pm$ $0.1, n=2$ ). All three potentiations were immediate (maximal from the first pulse applied $10 \mathrm{sec}$ after the change in condition) and fully reversible (data not shown). Moreover, all three potentiations were associated with a similar acceleration of the dissociation of glutamate as measured by the decrease in the time constant of the glutamate off-relaxation (Fig. $8 B$ ). The mean $\tau_{\text {off }}$ value was $139 \pm 7 \mathrm{msec}(n=7)$ in control conditions, $44 \mathrm{msec} \pm$ $12 \mathrm{msec}(n=4)$ in TPEN, $48 \pm 16 \mathrm{msec}(n=2)$ in DTE, and 41 msec $(n=1)$ in DTE plus TPEN. Similar current amplitudes of the responses recorded at $-60 \mathrm{mV}$ in the presence of DTE (3 $\mathrm{mM})$ alone and TPEN $(1 \mu \mathrm{M})$ plus DTE $(3 \mathrm{~mm})$ also were observed in Xenopus oocytes expressing NR1a-NR2A receptors $(n=6)$. Moreover, we observed that DTE ( $3 \mathrm{mM})$ fails to induce fast potentiation effects when applied in the presence of other 
$\mathrm{Zn}^{2+}$-chelating agents (100 $\mu \mathrm{M}$ EDTA; $1 \mathrm{~mm}$ ADA; $10 \mathrm{~mm}$ tricine; $1 \mu \mathrm{M}$ DTPA) (data not shown).

Therefore, the fast potentiations of NR1a-NR2A responses by DTE (or DTT) and by TPEN involve a similar mechanism. We propose that the NR2A subunit-specific potentiation of NMDA receptor activity by sulfhydryl reducing agents is caused by chelation of contaminant heavy metal traces, resulting in the relief of a tonic high-affinity inhibition. In the light of the data presented in this work, it seems most likely that $\mathrm{Zn}^{2+}$ is the contaminant metal.

\section{DISCUSSION}

Our observations show that the two inhibitory effects of $\mathrm{Zn}^{2+}$ (voltage-independent and voltage-dependent) previously described on native NMDA receptors by Christine and Choi (1990) and by Legendre and Westbrook (1990) also are observed in recombinant NMDA receptors. However, in one class of recombinant receptors (NR1a-NR2A or NR1b-NR2A), the voltageindependent inhibition presents two atypical properties. First, the $\mathrm{IC}_{50}$ of the inhibition is in the nanomolar range $(\sim 10$ and $70 \mathrm{nM}$ in NR1a-NR2A and NR1b-NR2A receptors, respectively), i.e., much lower than what previously had been measured in native receptors. Second, the inhibition is never complete, and saturation of the voltage-independent $\mathrm{Zn}^{2+}$ site only reduces the response by $70-80 \%$. While this work was in progress, qualitatively similar conclusions were reported by two other groups (Moshaver and Raymond, 1996; Williams, 1996).

\section{Consequences of the presence of a high-affinity and partial voltage-independent $\mathrm{Zn}^{2+}$ inhibition in NR1- NR2A receptors}

The effects of heavy metal chelators described in the present study suggest that contaminating traces of $\mathrm{Zn}^{2+}$ (or of another metal) may be sufficient to strongly inhibit NR1-NR2A receptors through the high-affinity $\mathrm{Zn}^{2+}$ binding site. This may account for some of the discrepancies concerning $\mathrm{Zn}^{2+}$ inhibition of NMDA receptors found in the literature. For example, Hori et al. (1987) were able to block NMDA responses with $\mathrm{Zn}^{2+}$ at micromolar concentrations in slices of rat brain cortex, whereas the same $\mathrm{Zn}^{2+}$ concentrations were ineffective in experiments of Hegstad et al. (1989). This could mean either that in the second case the NMDA receptors are insensitive to $\mathrm{Zn}^{2+}$ (as the authors believed) or, on the contrary, that the receptors are so sensitive to $\mathrm{Zn}^{2+}$ that the voltage-independent inhibition already was saturated by contaminating $\mathrm{Zn}^{2+}$ levels. The partial nature of this inhibition in NR1-NR2A receptors may reinforce such misleading conclusions: on a background of $\mathrm{Zn}^{2+}$ contamination, an exogenous $\mathrm{Zn}^{2+}$ application will bring the receptors from an already strongly inhibited state to a maximally inhibited state in which $\sim 20 \%$ of the maximal response persists. The small effect observed may be recognized falsely as indicating a very lowaffinity $\mathrm{Zn}^{2+}$ inhibition (see Grimwood et al., 1996). This illustrates the need for a systematic use of metal chelators in evaluating the "control" responses. The presence of contaminant $\mathrm{Zn}^{2+}$ under control conditions in the work of Williams (1996) also may explain the eightfold difference in affinities for $\mathrm{Zn}^{2+}$ of NR1a$\mathrm{NR} 2 \mathrm{~A}$ receptors reported in that study and this paper.

A second consequence of the high-affinity $\mathrm{Zn}^{2+}$ inhibition is that it leads to a reevaluation of the potentiations produced by DTT and glutathione on recombinant NMDA receptors (Köhr et al., 1994). These authors described two potentiations produced by reducing agents: one slow and irreversible, observed in all of the subtypes tested, and one fast, reversible, and specific to the NR1-NR2A combination. The similarity and the mutual occlusion between this fast potentiation and that produced by metal chelators suggest that the rapid and subunit-specific effects of the reducing agents are better explained by chelation of $\mathrm{Zn}^{2+}$ (or of another metal) contaminating extracellular solutions than by their reducing properties. This reinterpretation further suggests that the "slow" redox modulation of the NMDA receptor, which is sensitive to the mutation of two cysteines identified in the NR1 subunit by Sullivan et al. (1994), is the sole modulation involving redox processes and is not subunit-specific. After suppression of this modulation by mutation of the two cysteines, the residual potentiation observed in NR1-NR2A receptors corresponds to the effects of complexing the contaminant metal.

Using a chimera approach, Köhr et al. (1994) identified a domain in the N-terminal region of the NR2A subunit (between residues 250 and 400) responsible for the "fast redox modulation." This domain most likely contains some of the molecular determinants of the high-affinity voltage-independent $\mathrm{Zn}^{2+}$ binding site. The point mutagenesis experiments of Köhr et al. (1994) indicate that the cysteine residues contained in this domain are not involved in the subunit-specific potentiation, but the region contains other residues often involved in protein $\mathrm{Zn}^{2+}$ binding sites, like histidines, glutamates, or aspartates (for review, see Christianson, 1991), which may be good candidates for the site mediating the NR2A subunit-specific $\mathrm{Zn}^{2+}$ inhibition.

\section{The voltage-dependent $\mathrm{Zn}^{2+}$ block in recombinant NMDA receptors}

The voltage-dependent $\mathrm{Zn}^{2+}$ inhibition of recombinant NMDA receptors resembles that described by Christine and Choi (1990) and by Legendre and Westbrook (1990) in native receptors. It is similar in NR1-NR2A and NR1-NR2B receptors, which does not mean that it does not show subunit specificity: there are actually strong reasons to suppose that the voltage-dependent block by extracellular $\mathrm{Zn}^{2+}$ involves, at least in part, the same amino acids as the extracellular block by $\mathrm{Mg}^{2+}$ (see below), and it is known that the extracellular block by $\mathrm{Mg}^{2+}$ is more marked in NR1-NR2A and NR1-NR2B receptors than in NR1-NR2C and NR1-NR2D receptors (Kutsuwada et al., 1992; Monyer et al., 1992, 1994; Ishii et al., 1993; Kuner and Schoepfer, 1996; Momiyama et al., 1996). One is tempted to predict that in recombinant NR1-NR2C or NR1-NR2D receptors the voltagedependent $\mathrm{Zn}^{2+}$ block would be smaller than in NR1-NR2A or NR1-NR2B receptors.

Quantitatively, the differences between the $\mathrm{Mg}^{2+}$ block and the voltage-dependent $\mathrm{Zn}^{2+}$ block that were described in native receptors by Christine and Choi (1990) and by Legendre and Westbrook (1990) also were observed in recombinant receptors: the apparent voltage dependence of the $\mathrm{Zn}^{2+}$ block (calculated by comparing $\mathrm{Zn}^{2+}$ block at 0 and $-100 \mathrm{mV}$ ) was lower than that of $\mathrm{Mg}^{2+}(\delta$, the electrical depth of the binding site, was estimated to 0.5 for $\mathrm{Zn}^{2+}$ instead of $0.8-1$ for $\mathrm{Mg}^{2+}$; Ascher and Nowak, 1988; Jahr and Stevens, 1990). Such a difference could indicate that $\mathrm{Zn}^{2+}$ binds at a more superficial position in the pore than $\mathrm{Mg}^{2+}$. However, as already suggested by Christine and Choi (1990) and Legendre and Westbrook (1990), it more probably is attributable to the fact that $\mathrm{Zn}^{2+}$ permeates the channel more easily than $\mathrm{Mg}^{2+}$. Indeed, the voltage dependence of $\mathrm{Zn}^{2+}$ permeation has a polarity opposite to that of $\mathrm{Zn}^{2+}$ dissociation toward the extracellular compartment. When a significant proportion of the $\mathrm{Zn}^{2+}$ blocking ions dissociate from the blocking 
site toward the cytoplasm, the apparent voltage dependence of the block provides an underestimation of the depth of the blocking site. In such a permeation/block model, first developed by Woodhull (1973), the apparent voltage dependence of the block should depend on the voltage range in which it is measured because of the change in the relative contribution of the permeation and dissociation processes. This is what was observed in our experiments (see Fig. $5 D$ ), and the estimation of the $\mathrm{Zn}^{2+}$ block voltage dependence in the depolarized range $(-40$ to $0 \mathrm{mV} ; \delta=$ 0.77 ) is close to the voltage dependence of $\mathrm{Mg}^{2+}$ block.

The effect of the mutation NR2A(N595K), which suppresses both of the voltage-dependent $\mathrm{Zn}^{2+}$ and $\mathrm{Mg}^{2+}$ blocks without affecting the voltage-independent $\mathrm{Zn}^{2+}$ inhibition, provides further support for the hypothesis that in the NMDA channel the $\mathrm{Zn}^{2+}$ and $\mathrm{Mg}^{2+}$ blocking sites are very close (if not superimposed).

\section{Functional consequences of the high-affinity $\mathrm{Zn}^{2+}$ inhibitory site}

In most of the native receptors that we tested (on cortical and diencephalic neurons in primary cultures), the complexing of heavy metals produced a potentiation, which was, however, never as large as that observed with NR1a-NR2A recombinant receptors. This indicates that the native receptors were neither pure NR1-NR2B receptors (which are not potentiated by TPEN) nor pure NR1a-NR2A receptors (which are strongly potentiated by the chelators). Such a result, in fact, was expected, given the NMDA subunit heterogeneity revealed by recent RT-PCR studies on neurons (see Gibb and Wyllie, 1997). On the other hand, the presence of a potentiation confirms the early observation of Eimerl and Schramm (1992), who reported that in cultured neurones metal chelators such as EDTA, cysteine, or orthophenantroline produced a marked potentiation of the ${ }^{45} \mathrm{Ca}$ influx produced by NMDA agonists.

The same authors extended their observations to the NMDAinduced toxicity and concluded that the high sensitivity to $\mathrm{Zn}^{2+}$ of the NMDA receptors protects the neurons against glutamate neurotoxicity. This interesting conclusion, which contrasts with the fact that $\mathrm{Zn}^{2+}$ potentiates the responses of the other glutamate ionotropic receptors (Rassendren et al., 1990) (see also Smart et al., 1994), needs to be qualified in view of the recent observations of Koh et al. (1996), suggesting that the toxicity of $\mathrm{Zn}^{2+}$ is dependent in large part on $\mathrm{Zn}^{2+}$ entry into the neurons. If this is a general case, the voltage-dependent $\mathrm{Zn}^{2+}$ inhibition may not protect against excitotoxicity because it may be associated with a significant entry of $\mathrm{Zn}^{2+}$ (see above). In contrast, the voltage-independent $\mathrm{Zn}^{2+}$ inhibition may be viewed as truly protective and as such may give an advantage to NR1-NR2A receptors over NR1-NR2B receptors.

The levels of $\mathrm{Zn}^{2+}$ in the synaptic cleft in the intact brain are difficult to deduce from the data currently available. In particular, the relative amount of free $\mathrm{Zn}^{2+}$ versus bound $\mathrm{Zn}^{2+}\left(\mathrm{Zn}^{2+}\right.$ being avidly chelated by proteins) is not known. In any case, it seems clear that, if there are synaptic NMDA receptors with a nanomolar $\mathrm{Zn}^{2+}$ affinity, maximal efficacy for synaptic transmission requires the extracellular free $\mathrm{Zn}^{2+}$ level to be brought below $10 \mathrm{~nm}$. This could be achieved by $\mathrm{Zn}^{2+}$ chelation, but it also could involve the presence of powerful uptake systems, a notion that deserves investigation.

\section{REFERENCES}

Arslan P, Di Virgilio F, Beltrame M, Tsien RY, Pozzan T (1985) Cytosolic $\mathrm{Ca}^{2+}$ homeostasis in Ehrlich and Yoshida carcinomas. J Biol Chem 260:2719-2727.

Ascher P, Nowak L (1988) The role of divalent cations in the $N$-methylD-aspartate responses of mouse central neurones in culture. J Physiol (Lond) 399:247-266.

Ascher P, Bregestovski P, Nowak L (1988) N-methyl-D-aspartateactivated channels of mouse central neurones in magnesium-free solutions. J Physiol (Lond) 399:207-226.

Audinat E, Lambolez B, Rossier J, Crepel F (1994) Activity-dependent regulation of $N$-methyl-D-aspartate receptor subunit expression in rat cerebellar granule cells. Eur J Neurosci 6:1792-1800.

Bers D, Patton C, Nuccitelli R (1994) A practical guide to the preparation of Ca buffers. Methods Cell Biol 40:3-29.

Burnashev N, Schoepfer R, Monyer H, Ruppersberg JP, Gunther W, Seeburg PH, Sakmann B (1992) Control by asparagine residues of calcium permeability and magnesium blockade in the NMDA receptor. Science 257:1415-1419.

Chalfie M, Tu Y, Euskirchen G, Ward WW, Prasher DC (1994) Green fluorescent protein as a marker for gene expression. Science 263:802-805.

Chen C, Okayama H (1987) High-efficiency transformation of mammalian cells by plasmid DNA. Mol Cell Biol 7:2745-2752.

Christianson DW (1991) Structural biology of zinc. Adv Protein Chem 42:281-355.

Christine CW, Choi DW (1990) Effect of zinc on NMDA receptormediated channel currents in cortical neurons. J Neurosci 10:108-116.

Cornell NW, Crivaro KE (1972) Stability constant for the zinc-dithiothreitol complex. Anal Biochem 47:203-208.

Dawson RMC, Elliott DC, Elliott WH, Jones KM (1986) Data for biochemical research, 3rd Ed. New York: Oxford Science.

Eimerl S, Schramm M (1992) An endogenous metal appears to regulate NMDA receptor-mediated ${ }^{45} \mathrm{Ca}$ influx and toxicity in cultured cerebellar granule cells. Neurosci Lett 137:198-202.

Eimerl S, Schramm M (1993) Potentiation of ${ }^{45} \mathrm{Ca}$ uptake and acute toxicity mediated by the $N$-methyl-D-aspartate receptor: the effect of metal binding agents and transition metal ions. J Neurochem 61:518-525.

Forsythe ID, Westbrook GL, Mayer ML (1988) Modulation of excitatory synaptic transmission by glycine and zinc in cultures of mouse hippocampal neurons. J Neurosci 8:3733-3741.

Gibb AJ, Wyllie DJA (1997) Single-cell RT-PCR reaches out to the NMDA receptor. J Physiol (Lond) 499:1.

Grimwood S, Hutson PH, Macaulay AJ, Priestley T (1996) Subtypespecific modulation of stably expressed recombinant human $N$-methylD-aspartate receptors by zinc ions. Soc Neurosci Abstr 22:507.11.

Hamill O, Marty A, Neher E, Sakmann B, Sigworth F (1981) Improved patch-clamp techniques for high-resolution current recording from cells and cell-free membrane patches. Pflügers Arch 391:85-100.

Hegstad E, Langmoen IA, Hablitz JJ (1989) Zinc and glycine do not modify low-magnesium-induced epileptiform activity in the immature neocortex in vitro. Epilepsy Res 3:174-177.

Hollmann M, Boulter J, Maron C, Beasley L, Sullivan J, Pecht G, Heinemann S (1993) Zinc potentiates agonist-induced currents at certain splice variants of the NMDA receptor. Neuron 10:943-954.

Hori N, Galeno T, Carpenter DO (1987) Responses of pyriform cortex neurons to excitatory amino acids: voltage dependence, conductance changes, and effects of divalent cations. Cell Mol Neurobiol 7:73-90.

Ishii T, Moriyoshi K, Sugihara H, Sakurada K, Kadotani H, Yokoi M, Akazawa C, Shigemoto R, Mizuno N, Masu M, Nakanishi S (1993) Molecular characterization of the family of the $N$-methyl-D-aspartate receptor subunits. J Biol Chem 268:2836-2843.

Jahr CE, Stevens CF (1990) Voltage dependence of NMDA-activated macroscopic conductances predicted by single-channel kinetics. J Neurosci 10:3178-3182.

Kawajiri S, Dingledine R (1993) Multiple structural determinants of voltage-dependent magnesium block in recombinant NMDA receptors. Neuropharmacology 32:1203-1211.

Koh JY, Choi DW (1988) Zinc alters excitatory amino acid neurotoxicity on cortical neurons. J Neurosci 8:2164-2171.

Koh JY, Suh SW, Gwag BJ, He YY, Hsu CY, Choi DW (1996) The role of zinc in selective neuronal death after transient global cerebral ischemia. Science 272:1013-1016.

Köhr G, Eckardt S, Luddens H, Monyer H, Seeburg PH (1994) NMDA 
receptor channels: subunit-specific potentiation by reducing agents Neuron 12:1031-1040.

Kuner T, Schoepfer R (1996) Multiple structural elements determine subunit specificity of $\mathrm{Mg}^{2+}$ block in NMDA receptor channels. J Neurosci 16:3549-3558.

Kunkel TA (1985) Rapid and efficient site-specific mutagenesis without phenotypic selection. Proc Natl Acad Sci USA 82:488-492.

Kupper J, Ascher P, Neyton J (1996) Probing the pore region of recombinant $N$-methyl-D-aspartate channels using external and internal magnesium block. Proc Natl Acad Sci USA 93:8648-8653.

Kutsuwada T, Kashiwabuchi N, Mori H, Sakimura K, Kushiya E, Araki K, Meguro H, Masaki H, Kumanishi T, Arakawa M, Mishina M (1992) Molecular diversity of the NMDA receptor channel. Nature 358:36-41.

Legendre P, Westbrook GL (1990) The inhibition of single $N$-methyl-Daspartate-activated channels by zinc ions on cultured rat neurones. J Physiol (Lond) 429:429-449.

Leonard JP, Kelso SR (1990) Apparent desensitization of NMDA responses in Xenopus oocytes involves calcium-dependent chloride current. Neuron 4:53-60.

Mayer ML, Vyklicky Jr L (1989) The action of zinc on synaptic transmission and neuronal excitability in cultures of mouse hippocampus. J Physiol (Lond) 415:351-365.

Mayer ML, Westbrook GL, Guthrie PB (1984) Voltage-dependent block by $\mathrm{Mg}^{2+}$ of NMDA responses in spinal cord neurones. Nature 309:261-263.

Mayer ML, Westbrook GL, Vyklicky Jr L (1988) Sites of antagonist action on $N$-methyl-D-aspartic acid receptors studied using fluctuation analysis and a rapid perfusion technique. J Neurophysiol 60:645-663.

Mayer ML, Vyklicky Jr L, Westbrook GL (1989) Modulation of excitatory amino acid receptors by group IIB metal cations in cultured mouse hippocampal neurones. J Physiol (Lond) 415:329-350.

McBain CJ, Mayer ML (1994) $N$-methyl-D-aspartic acid receptor structure and function. Physiol Rev 74:723-760.

Meguro H, Mori H, Araki K, Kushiya E, Kutsuwada T, Yamazaki M, Kumanishi T, Arakawa M, Sakimura K, Mishina M (1992) Functional characterization of a heteromeric NMDA receptor channel expressed from cloned cDNAs. Nature 357:70-74.

Momiyama A, Feldmeyer D, Cull-Candy SG (1996) Identification of a native low-conductance NMDA channel with reduced sensitivity to $\mathrm{Mg}^{2+}$ in rat central neurones. J Physiol (Lond) 494:479-492.

Monyer H, Sprengel R, Schoepfer R, Herb A, Higuchi M, Lomeli H, Burnashev N, Sakmann B, Seeburg PH (1992) Heteromeric NMDA receptors: molecular and functional distinction of subtypes. Science 256:1217-1221.

Monyer H, Burnashev, N, Laurie DJ, Sakmann B, Seeburg PH (1994) Developmental and regional expression in the rat brain and functional properties of four NMDA receptors. Neuron 12:529-40.

Mori H, Masaki H, Yamakura T, Mishina M (1992) Identification by mutagenesis of a $\mathrm{Mg}^{2+}$-block site of the NMDA receptor channel. Nature 358:673-675.

Moriyoshi K, Masu M, Ishii T, Shigemoto R, Mizuno N, Nakanishi S (1991) Molecular cloning and characterization of the rat NMDA receptor. Nature 354:31-37.

Moshaver A, Raymond LA (1996) Differential sensitivity of recombinant NMDA receptor subtypes to zinc: implications for glutamate excitotoxicity. Soc Neurosci Abstr 22:671.2.
Nowak L, Bregestovski P, Ascher P, Herbet A, Prochiantz A (1984) Magnesium gates glutamate-activated channels in mouse central neurones. Nature 307:462-465.

Paoletti P, Neyton J, Ascher P (1995) Glycine-independent and subunitspecific potentiation of NMDA responses by extracellular $\mathrm{Mg}^{2+}$. Neuron 15:1109-1120.

Peters S, Koh J, Choi DW (1987) Zinc selectively blocks the action of $N$-methyl-D-aspartate on cortical neurons. Science 236:589-593.

Premkumar LS, Auerbach A (1996) Identification of a high-affinity divalent cation binding site near the entrance of the NMDA receptor channel. Neuron 16:869-880.

Rassendren FA, Lory P, Pin JP, Nargeot J (1990) Zinc has opposite effects on NMDA and non-NMDA receptors expressed in Xenopus oocytes. Neuron 4:733-740.

Sakurada K, Masu M, Nakanishi S (1993) Alteration of $\mathrm{Ca}^{2+}$ permeability and sensitivity to $\mathrm{Mg}^{2+}$ and channel blockers by a single amino acid substitution in the $N$-methyl-D-aspartate receptor. J Biol Chem 268:410-415.

Sather W, Dieudonné S, MacDonald JF, Ascher P (1992) Activation and desensitization of $N$-methyl-D-aspartate receptors in nucleated outsideout patches from mouse neurones. J Physiol (Lond) 450:643-672.

Smart TG, Xie X, Krishek BJ (1994) Modulation of inhibitory and excitatory amino acid receptor ion channels by zinc. Prog Neurobiol 42:393-441.

Sullivan JM, Traynelis SF, Chen HS, Escobar W, Heinemann SF, Lipton SA (1994) Identification of two cysteine residues that are required for redox modulation of the NMDA subtype of glutamate receptor. Neuron 13:929-936.

Trombley PQ, Shepherd G (1996) Differential modulation of zinc and copper of amino acid receptors from rat olfactory bulb neurons. J Neurophysiol 76:2536-2546.

Vlachova V, Zemkova H, Vyklicky Jr L (1996) Copper modulation of NMDA responses in mouse and rat cultured hippocampal neurons. Eur J Neurosci 8:2257-2264.

Westbrook GL, Mayer ML (1987) Micromolar concentrations of $\mathrm{Zn}^{2+}$ antagonize NMDA and GABA responses of hippocampal neurons. Nature 328:640-643.

Williams K (1994) Subunit-specific potentiation of recombinant $N$-methylD-aspartate receptors by histamine. Mol Pharmacol 46:531-541.

Williams K (1996) Separating dual effects of zinc at recombinant $N$-methyl-D-aspartate receptors. Neurosci Lett 215:9-12.

Williams K, Russell SL, Shen YM, Molinoff PB (1993) Developmental switch in the expression of NMDA receptors occurs in vivo and in vitro. Neuron 10:267-278.

Williams K, Zappia AM, Pritchett DB, Shen YM, Molinoff PB (1994) Sensitivity of the $N$-methyl-D-aspartate receptor to polyamines is controlled by NR2 subunits. Mol Pharmacol 45:803-809.

Woodhull AM (1973) Ionic blockade of sodium channels in nerve. J Gen Physiol 61:687-708.

Zhang L, Zheng X, Paupard MC, Wang AP, Santchi L, Friedman LK, Zukin RS, Bennett MV (1994) Spermine potentiation of recombinant $N$-methyl-D-aspartate receptors is affected by subunit composition. Proc Natl Acad Sci USA 91:10883-10887.

Zheng X, Zhang L, Durand GM, Bennett MV, Zukin RS (1994) Mutagenesis rescues spermine and $\mathrm{Zn}^{2+}$ potentiation of recombinant NMDA receptors. Neuron 12:811-818. 